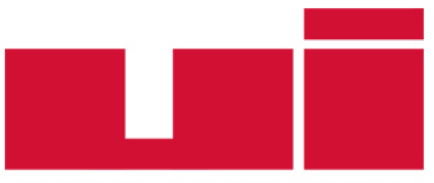

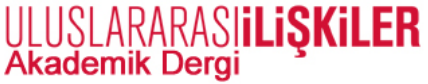

Yayın ilkeleri, izinler ve abonelik hakkında ayrıntılı bilgi:

E-mail: bilgi@uidergisi.com.tr

Web: www.uidergisi.com.tr

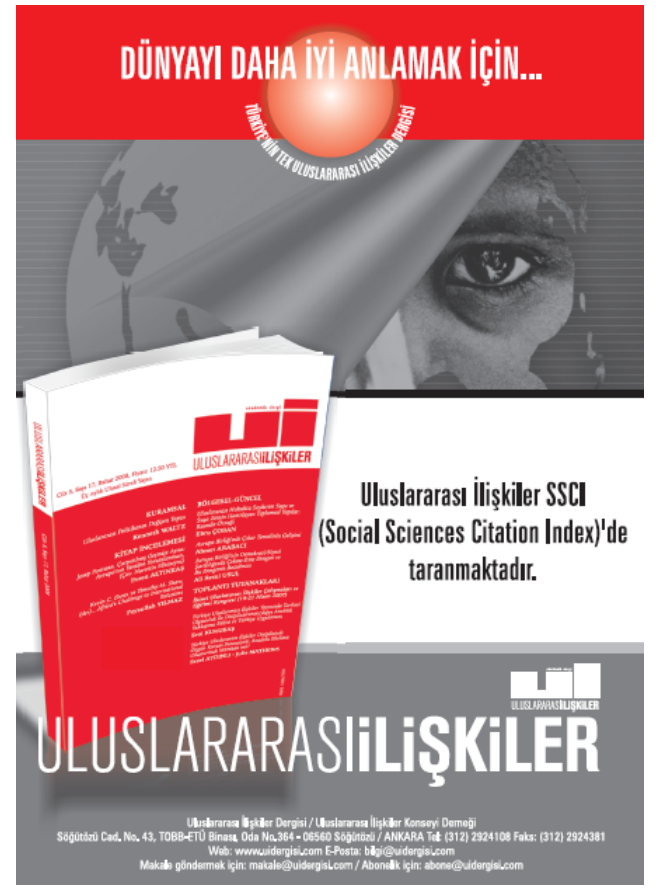

\title{
Pierre Bourdieu'nun Uluslararası İlişkiler Kuramlarına Olası Katkıları
}

\author{
Hüseyin SEVİM* \\ * Dr. , Université de Perpignan Via Domitia, \\ Siyaset Bilimi Bölümü
}

Bu makaleye atıf için: Sevim, Hüseyin, "Pierre Bourdieu'nun Uluslararası İlişkiler Kuramlarına Olası Katkıları", Uluslararası Illişkiler, Cilt 11, Say1 43 (Güz 2014), s. 7-32.

Bu makalenin tüm hakları Uluslararası İlişkiler Konseyi Derneği'ne aittir. Önceden yazılı izin alınmadan hiç bir iletişim, kopyalama ya da yayın sistemi kullanılarak yeniden yayımlanamaz, çoğaltılamaz, dağıtılamaz, satılamaz veya herhangi bir şekilde kamunun ücretli/ücretsiz kullanımına sunulamaz. Akademik ve haber amaçlı kısa alıntılar bu kuralın dışındadır.

Aksi belirtilmediği sürece Uluslararası Illişkiler'de yayınlanan yazılarda belirtilen fikirler yalnızca yazarına/yazarlarına aittir. UİK Derneğini, editörleri ve diğer yazarları bağlamaz. 


\title{
Pierre Bourdieu'nun Uluslararası İlişkiler Kuramlarına Olası Katkıları
}

Hüseyin SEVİ**

\section{ÖZET}

$\mathrm{Bu}$ makale Pierre Bourdieu'nun Uluslararası İlişkiler kuramlarına etkisini değerlendiren çalışmaların hala çok yetersiz olduğu düşüncesinden hareket ederek, Bourdieu'nun geliştirdiği düşünce ve kavramlara odaklanmakta ve onun Uluslararası İlişkiler disiplinine ne gibi katkılar getirebileceğini tartışmaktadır. Bunun için de önce Bourdieu'cü analizin epistemolojik ve ontolojik sorunları nasıl değerlendirdiğini tartıştıktan sonra, onun başlıca düşünce ve kavramlarından hareket ederek, bunları Uluslararası İlişkiler kuramlarına uyarlamayı hedeflemektedir. Bu makalenin temel tezi Ululararası İlişkiler disiplini içerisindeki meta-teorik anlamdaki diyalog eksikliğinin Bourdieu'cü perspektifle bir nebze olsun aşılabileceğidir. Diğer bir ifadeyle, Ululararası İlişkiler disiplinindeki paradigmalar arasındaki bütünleyiciliğin mümkün olabileceği ve Bourdieu'nün geliştirdiği kavramların ana akım kuramların yetersizliklerini ve kör noktalarını bir nebze olsun azaltabileceğini iddia edilmektedir.

Anahtar Kelimeler: Pierre Bourdieu, Epistemoloji ve Ontoloji,Uluslararası İlişkiler Kuramları.

\section{Pierre Bourdieu's Potential Contributions to The Theories of International Relations}

\begin{abstract}
The studies have investigated on the impact of Pierre Bourdieu on the theories of International Relations (IR) are still insufficient. This article aims to analyze how Bourdieu can contribute to the discipline of International Relations. In this context, it will first cover the discussions on how Bourdieusian analysis has evaluated epistemologic and ontologic problems, it will then adapt the main ideas and concepts of Bourdieu to the IR. The main thesis of this article is that Bourdieusian perspectif provides convincing answers to the problems that exist within the discipline of International Relations at the meta-theoretical level. In otherwise, it argues that the inter-paradigmatic complementarity is possible within the discipline and the concepts have developped by Pierre Bourdieu allow to fill the gaps of the mainstreams theories.
\end{abstract}

Keywords: Pierre Bourdieu, Epistemology and Ontology, Theories of Internationals Relations.

* Dr., Siyaset Bilimi Bölümü, Université de Perpignan Via Domitia, Fransa. E-posta: huseyinsevim1@gmail.com. Eleştiri, öneri ve katkılarından ötürü iki hakeme ve Prof. Dr. Faruk Yalvaç'a teşekkür ederim. 


\section{Giriş}

Pierre Bourdieu'nün geliştirdiği kavramlar sosyoloji ve antropoloji disiplinlerine büyük katkıda bulunmuşsa da, Uluslararası İlişkiler ${ }^{1}$ kuramlarına etkisi sınırlı kalmıştır. Bunun nedeni bazılarına göre hem çalı̧malarının yeterince önemsenmemesinde, hem de onun ortaya attığı düşüncelerin Uluslararası İlişkiler disiplininde alana hâkim kuramların savunduğu geleneksel araştırma yöntemlerini istikrarsızlaştıracak olmasında yatmaktadır. ${ }^{2}$ Bazılarına göre ise bu etkinin sınırlı kalması Bourdieu'nün çalı̧malarını daha ziyade ulusal alandaki problematiklerle sinırlı tutmasinda yatmaktadır. ${ }^{3} \mathrm{Bu}$ nedenle de Bourdieu'nün savunduğu fikirlerin Uluslararası İlişkiler'e aktarılması oldukça geç gerçekleşmiştir. Nihayetinde Rebecca Adler-Nissen'in de ifade ettiği gibi Pierre Bourdieu'nün Uluslararası İlişkiler kuramlarına etkisini değerlendiren çalışmalar hala çok yetersizdir. ${ }^{4}$ Oysa onun geliştirdiği özgün yaklaşımlar sosyal bilimlerdeki epistemolojik ve ontolojik kavramsal kargaşalara somut cevaplar getirmenin yanı sıra, Uluslararası İlişkiler kuramlarındaki mevcut katı ikiliklerin (dichotomie) $)^{5}$ de aşılmasına bir nebze yardımcı olmaktadır.

Bourdieu'cü düşüncenin anlaşılması ve Uluslararası İlişkiler disiplinine ne gibi katkılar getirebileceği eserlerinin yeniden okunmasını ve bir literatür taramasını gerekli kılmaktadır. Bourdieu'nün düşüncelerini Ululararası İlişkiler kuramlarıyla karşılaştırmay1 denemek kuşkusuz yeni bir durum değil, örneğin Richard Ashley ve Didier Bigo Bourdieu'nün bazı kavramlarından yararlanarak bu alanda önemli adımlar atmışlardır. Bu çalı̧̧malara her geçen gün yenileri de eklenmektedir. ${ }^{8}$ Bu makaledeki amaç, Ululararası

$1 \mathrm{Bu}$ makale de doğrudan disipline gönderme yapıldığında Uluslararası İlişkiler ifadesi kullanılacaktır; aksine uluslararası sistemdeki çeşitli eyleyenler arasındaki ilişkiler bütününe atıf yapıldığında söz konusu ifade küçük harflerle belirtilecektir.

2 Didier Bigo, "Pierre Bourdieu and International Relations: Power of Practices, Practices of Power", International Political Sociology, Cilt 5, No.3, 2011, s.225.

3 Frédéric Mérand ve Vincent Pouliot, "Le Monde de Pierre Bourdieu: Éléments pour une Théorie Sociale des Relations internationales", Canadian Journal of Political Science, Cilt 41, No.3, 2008, s.603. Ölümünden önceki birkaç yayını buna istisna teşkil edebilir, örneğin bkz. Pierre Bourdieu, Contre-feux 1. Propos pour Servir à la Résistance contre l'Invasion Néo-libérale, Paris, Liber/Raisons d'Agir, 1998: Pierre Bourdieu, Contre-feux 2, Paris, Raisons d'Agir, 2001.

4 Rebecca Adler-Nissen, "Bourdieu and International Relations Theory", Rebecca Adler-Nissen (der.), Bourdieu in International Relations- Retbinking Key Concept in IR, New York, Routledge, 2013, s.1-23.

5 Bu makalede Bourdieu tarafından kullanılan terminoloji Türkçe karşılığı olduğu ölçüde Türkçeye çevrilmiştir. Türkçe karşılığı bulunmadığı veya mevcut karşılıkların istenilen ifadeyi tam olarak karşılamadığı durumlarda yazarın kastetdiği kavrama en yakın çeviri kabul edilip Bourdieu tarafindan kullanılan terminolojinin orijinali metine aktarılmıştır.

6 Richard K. Ashley, “The Poverty of Neorealism”, International Organization, Cilt 38, No.2, 1984, s.225-286.

7 Didier Bigo, Polices en Réseaux: l'Expérience Européenne, Paris, Presses de Sciences Po., 1996.

8 Bourdieu ve Uluslararası İlişkiler kuramları konusundaki güncel çalışmalar için bkz. Emanuel Adler ve Vincent Pouliot, International Practices, New York, Cambridge University Press, 2011; Michael C. Williams, Culture and Security: Symbolic Power and the Politics of International Security, Londra, Routledge, 2007; David L. Swartz ve Vera L. Zolberg (der.), After Bourdieu, Dordrecht, Kluwer, 2004; Didier Bigo ve Anastassia Tsoukala (der.), Terror, Insecurity and Liberty- Illiberal 
İlişkiler disiplinindeki ana akım kuramların iddialarını çürütmekten ziyade, disiplin içerisindeki diyalog eksikliğinin, Bourdieu'nün düşüncelerinden ve kavramlarından faydalanarak, asgariye çekilebileceğini göstermektir. Diğer bir ifadeyle söz konusu makale belirli bir örnek olayı ayrıntılı incelemektense, Bourdieu'cü düşüncenin ne şekilde Uluslararası İlişkiler kuramlarına aktarılabileceğine değinip, meta-teorik alanda Ululararası İlişkiler disiplinindeki paradigmalar arası bütünleyiciliğin mümkün olabileceğini ve Bourdieu'nün geliştirdiği kavramların ana akım kuramların yetersizliklerini ve kör noktalarını bir nebze olsun azaltabileceğini iddia etmektetir. Bu çerçevede makale öncelikle Bourdieu'nün sosyal bilimlere meta-teorik anlamda katkısını tartıştıktan sonra kendisinin kullandığı bazı kavramlardan hareket ederek bunların Uluslararası İlişkiler kuramlarına ne şekilde uyarlanabileceğini göstermeyi hedeflemektedir.

\section{Epistemoloji Tartışmalarında Bourdieu'nun “Orta Yol” Arayışları}

Yetmişli yıllarda Uluslararası İlişkiler kuramları konusunda ortaya çıkan tartı̧malarda liberal ve Marksist akımı savunanlar o zamana kadar alana hakîm olan Gerçekçi kuramın özellikle iki unsurunu eleştirmekteydiler: bunlardan ilki bu yaklaşımın devlet-merkezli indirgemeci analiziydi. Bu bağlamda Gerçekçi paradigmanın uluslararası ilişkileri kavrayış tarzı, diğer bir ifadeyle ontolojisi reddedilmekteydi. İkinci unsur ise, Gerçekçi paradigmanın karamsarlık ve uluslararası ilişkilerdeki status quo yanlısı eğilimleri üzerine kurulu normativitesiyle ilgiliydi. Daha açık bir ifadeyle Gerçekçi paradigmanın oluşturduğu normlar ve bilgiyi edinme biçimleri, yani epistemolojisi eleştirilmekteydi. Disiplin içerisinde hem ontolojik hem de epistemolojik bir kopuşun ortaya çıktığı bu dönemde, bir yanda uluslararası sistemin sorunlarını çözmeye yönelik oluşturulan kuramlar, diğer yanda ise Uluslararası İlişkiler kuramlarının temellerini ve bunların üzerine inşa edildiği uygulamaları sorgulayan akımların bulunduğunu söylemek mümkün. ${ }^{9} \mathrm{Bu}$ tartışmalar nihayetinde neo-pozitivistlerle post-pozitivistler arasında epistemolojik bir ayrillğa neden olacak, bu kopuş bazılarını Uluslararası İlişkiler disiplini içerisinde "yeni bir çağın” başlangııını ilan etmeye kadar sürekleyecektir ${ }^{10}$. Söz konusu epistemolojik kopuş disiplin içerisinde doğa bilimleri metodlarını benzer yöntemlerle sosyal bilimlere uyarlayarak uluslararası siyasi sorunlar konusunda genellemeler elde etmeye çalı̧an ana akım tabir edilen kuram

Practices of Liberal Regimes After 9/11, New York, Routledge, 2008; Jeremy F. Lane, Bourdieu's Politics- Problems and Possibilities, New York, Routledge, 2006; Rebecca Adler- Nissen (der.), Bourdieu in International Relations- Retbinking Key Concepts in IR, New York, Routledge, 2013; Anna Leander, "The Power to Construct International Security: On the Signifiance of Private Military Companies", Millenium Journal of International Studies, Cilt 33, No.3, 2005, s.803-826; Anna Leander, "The Promises, Problems, and Potentials of a Bourdieu-Inspired Staging of International Relations", International Political Sociology, Cilt 5, No.3, 2011, s.294-313.

9 Robert W. Cox, "Social Forces, States and World Order: Beyond International Relations Theory", Robert O. Keohane (der.), Neorealism and its Critics, New York, Columbia University Press, 1986, s.208.

10 Yosef Lapid, "The Third Debate: On the Prospects of International Theory in a Post-Positivist Era”, International Studies Quarterly, Cilt 33, No.3, 1989, s.235-254. 
savunucularının karşısına bilginin doğasını sorgulayan ve dilin (language) anlamlar üretme ve performatif gücünde (puissance performative) 1srar eden eleştirel kuram savunucularını çıkaracaktır. Bourdieu'nun ortaya attığ1 düşünümsel epistemoloji (épistémologie réflexive) de Uluslararası İlişkiler disiplini bünyesinde gerek kuramsal gerekse metodolojik yöntemlerin ciddi anlamda sorgulandığı bir zamana denk düşecektir.

Peki, Bourdieu ne öneriyordu? Ona göre herşeyden önce, grubun veya bireyin tarihsel özelliklerini dikkate almadan inşa edilen ve daha sonra bunları bütünlere (totality/ totalité) dönüştürüp objektif ilişkiler sistemi gibi soyut bir gerçeklik gibi aktaran yap1nın gerçekliğinden (le réalisme de la structure) kurtulmak gerekiyordu. Bunun için de opus operatum ${ }^{11}$ prensibinden modus operandi’ye yönelmenin gerekli olduğunu düşünmekteydi. Diğer bir ifadeyle istatistiki düzenlilik veya cebirsel yapılardan uzaklaşarak gözlemlenen söz konusu düzenin üretim ilkelerine yönelip bir uygulama kuramı inşa edilmesini telkin etmekteydi. Bu durum ona göre "dışsallık ve içsellik diyalektiğinin (dışsallığın içselleştirildiği ve içselliğin dişsalaştırıldığı) oluşabileceği deneysel (expérimentale) bir bilim inşa etmek için vazgeçbilmez" bir koşuldu. ${ }^{12}$ Buna karşın Bourdieu pozitivizmin tüm ilkelerini reddetmemekteydi. Örneğin pozitivizmin döngüsel safhalarını (gözlem, hipotez, deneysellik ve kuram oluşturma süreci gibi zincirleme kurgusunu) yararlı bulmakla beraber, epistemolojik işlemler bağlamında bu zincirsel mekanizma ve kesitleme (işlemlerin birbirinden ayrılması anlamında) mantığını "gerçeğin" meydana geliş silsilesini eksik aksettirdiği için yanıltıcı bulmaktaydı. Ona göre bu şekilde oluşturulan bir epistemolojik kurgu, eylemlerin mantık düzenini kavramakta güçlük çekmekteydi, bunun nedeni de bu tür eylemlerin hiç bir zaman araştırmanın somut işlem kronolojisine indirgenemeyecek olmasıyd.. ${ }^{13}$ Oysa Ido Oren'in de ifade ettiği gibi Uluslararası İlişkiler disiplini içerisindeki çalışmalar genelde doğa bilimlerine uyarlanacak şekilde tasarlanmıştır, bu bağlamda da araştırmacılar tarihsel verileri geniş bir olaylar repertuarı gibi görüp bunları oluşturulacak genellemeleri doğrulamak amacıyla dikkate almışlardır. ${ }^{14}$ Bu bağlamda da pozitivist epistemoloji eyleyen ve yapı ilişkisini düşünürken bunları ayrı iki entite ve zıt ilişkiler kurgusunda tasarlamıştır. ${ }^{15}$

$\mathrm{Bu}$ nedenle de Bourdieu bizi çevreleyen gerçekliklerin anlaşılması ve izah edilmesi için farklı tekniklerin öneminin akılda tutulması gerektiğinin altını çizmekteydi. Ona

11 Bourdieu Langage et Pouvoir Symbolique adlı eserinde opus operatum ilkesini yeni-Kantçı felsefeye gönderme yaparak bu ilkeyi "bilincin üretim etkinlikleri” olarak anlamaktadır. Modus operandi ilkesini ise yapısalcı (structuralisme) geleneğe dayanarak "yapılandırılmış yapılar" (structures structurées) olarak izâh etmektedir. Ayrnntılı bilgi için bkz. Pierre Bourdieu, Langage et Pouvoir Symbolique, Paris, Éditions du Seuil, 2001, s.201-211.

12 Pierre Bourdieu, Esquisse d'une Théorie de la Pratique-Précédé de Trois Études d'Ethnologie Kabyle, Paris, Éditions du Seuil, 2000, s.256.

13 Pierre Bourdieu et.al., Le Métier de Sociologue, Paris, Éditions Minuit, 4’ncü bask1, 1983, s.82.

14 Ido Oren, "Political Science As History: A Reflexive Approach", Dvora Yanow ve Peregrine Schwartz-Shea (der.), Interpretation and Method-Empirical Research Methods and the Interpretive Turn, New York, M.E Sharpe, 2006, s.217.

15 Bill McSweeney, Security, Identity and Interest- A Sociology of International Relations, Cambridge, Cambridge University Press, 1999, s.143. 
göre pozitivist epistemoloji bütün nesneleri tek ve aynı bir teknikle açıklama çabasıyla farklı tekniklerle ortaya çıkarılabilecek olan nesnenin varoluşsal özelliklerini gözden kaçırmaktaydı. ${ }^{16}$ Pozitivizmin dı̧̧ında Bourdieu aynı zamanda post-modern akıma, özellikle de onun sosyal dünyayı metinlere indirgeyen göstergebilim hareketine (mouvance sémiotique) de karşı çıkmaktayd ${ }_{1}{ }^{17} \mathrm{Bu}$ bağlamda yapıbozumcuyu (déconstructeur) yap1bozuma (déconstruction) uğratmayı unutan post-modern akımın savunucularına yapıbozumcunun içinde bulunduğu habitus'u da dikkate almalarını telkin etmekteydi. Ona göre bu durumu görmezden gelmek eleştirinin oluştuğu sosyal temelleri "iskalamak" anlamına gelmekteydi.

Positivizm ile post-positivizm arasındaki kutuplaşmalara karşı çıkmanın yanı sıra Bourdieu aynı zamanda sosyal bilimlerde var olan ve sosyal gerçekliği elde etmeye yönelik yapay bir şekilde oluşturulan ikili çatışkıları (örneğin birey/toplum; uzlaşma/çatışma veya yap1 (structure)/eyleyen (agent/agency) ${ }^{18}$ gibi) da reddetmekteydi. ${ }^{19}$ Ona göre sosyal gerçekliğin ortaya çıkarılması sürecinde meydana gelen bu tür epistemolojik kutuplaşmalar nihayetinde bireylerin etkileşimlerini yapının doğasıyla özdeşletiren öznelci tutumla (subjectivité) yapının özelliklerini bireysel etkileşimlere indirgeyen nesnelci tutumu (objectivité) karşı karşıya getirmekteydi. ${ }^{20}$ Dolayısıyla Bourdieu yukarıda bahsedilen bu tür katı zıtlık ve ikilikler üzerine kurulu kavramsal sistemleri reddedip, bunları aşma cabaşında olmuştur. Bu konularla ilgili olarak da düşüncelerinin kaynağını Gaston Bachelard'ın epistemoloji konusundaki felsefi yaklaşımlarından almaktayd. Epistemoloji tartışmalarındaki bahsi geçen bu kutuplaşmalardan uzaklaşmak için, Accardo ve Corcuff'un da ifade ettiği gibi, sübjektivite ile objektivite arasındaki ilişkiyi yeniden düşünmek ve bunlardan birinden bahsederken aslında aynı olgulara işaret ettiğimizi göstermek gerekiyordu. Neden ? Çünkü insanın bulunduğu düzende varoluşsal sosyal koşullar (dışsal faktörler gibi) bireyler tarafindan içselleştirilmişlerdir. Söz konusu sosyal koşullar bir defa yapılandırıldığında, bu durum bireyler ve gruplar nezninde alg1, tasvir, düşünce, inanç ve arzu oluşturma süreçlerini tetiklemektedir. Ve bu durum birey ve grupların eylemleri vasıtasıyla sürekli yinelenmektedir. ${ }^{21} \mathrm{Bu}$ bağlam da, "içselliğin dışsallaşması ve dışsallığın içsel-

16 Bourdieu et.al., Le Métier de Sociologue, s.71.

17 Francisco Vazquez Garcia, "La Tension Infinie entre l'Histoire et la Raison: Foucault et Bourdieu”, Revue Internationale de Philosophie, No.220, 2002, s.343-365.

18 İngilizce de agency, Fransızca da ise agent olarak bulabileceğimiz kavram Türkçeye, özellikle de sosyal bilimler alanına, aktarılırken farklı şekillerde aktarılmıştır. Latince de agere'ye tekabül eden bu nosyon, genel olarak birey veya bireyliği olan bir varlığın (devlet gibi) eylemi yapması (eylemesi) olarak kabul edilmektedir. Bu makale de agency/agent kavramı "eyleyen" olarak kabul edilecektir, zira eyleyen kavramı eyleyenin icra ettiği/yaptığ 1 somut şeylere doğrudan gönderme yapmanın ötesinde eyleyenin eylemine soyut (örneğin Bourdieu'de sembolik güç/ iktidar kavramında olduğu gibi) aksiyonları da eklemektedir. Bourdieu’nün agent kavramıyla ilgili ayrıntıll görüşleri için bkz. Pierre Bourdieu, Le Sens Pratique, Paris, Editions Minuit, 1980; Pierre Bourdieu, Choses Dites, Paris, Éditions Minuit, 1987; Pierre Bourdieu, Méditations Pascaliennes, Paris, Éditions du Seuil, 2003.

19 Bourdieu, Méditations Pascaliennes, s.145-146.

20 Bourdieu, Choses Dites, s.152.

21 Alain Accardo ve Philippe Corcuff, La Sociologie de Bourdieu- Textes Choisis et Commentés, 
leştirilmesi” diyalektiği mantığını ön planda tutarak bilimsel bilginin üretim koşullarını daha somut bir şekilde elde etmeyi hedefleyen Bourdieu aslında düşünsel epistemoloji (épistémologie réflexive) kurgusuyla objektivizm ile sübjektivizm arasındaki bağlantıyı kurma çabasında olmuştur. Bunu da ortaya koyacağı "orta yol (voie médiane)" bir kuramla tesis etmeye çalışacaktır.

Bourdieu'cü düşünsel epistemolojinin katkısını epistemolojik alandaki çatışkılara getirdiği cevaplarla sınırlı tutmamak gerekir. Bachelard'ın epistemoloji çalışmalarını yeniden gözden geçiren Bourdieu bir de bunlara bilimsel çalı̧maların inşa edildiği sosyal koşullar analizini katmayı teklif etmiştir. ${ }^{22}$ Sosyal koşullar analizi "aynanın" bilimsel akıl ve bilimsel üretim koşullarına geri yöneltilmesi mantığ1 üzerine kuruludur. Bu durum bilginin ortaya çıktığı sosyal koşulların da epistemoloji çalışmalarında göz önünde tutulmasını gerektirmektedir. ${ }^{23}$ Daha açık bir ifadeyle, Bourdieu aslında araştırmacıların ürettiği bilimsel çalı̧̧malara uygulanması gereken bir "öz-nesnelliğin” (auto-objectivation) işletilmesini telkin etmekteydi. Bu durum ona göre bilginin oluşturulduğu sürece de odaklanılmasını olanaklı k1lıyordu. Bu durumu da "nesnelliğin nesnelleştirilmesi" (objectiver l'objectivation) olarak özetlemekteydi. ${ }^{24}$ Ona göre düşünselliğin düşünü (la réflexivité de la réflexion) özellikle bilimsel uygulamadaki tarihsel ve sosyal determinizmin etkilerini sınırlandırmak için önemli bir unsur teşkil ediyordu. ${ }^{25}$

Düşünsel epistemolojinin diğer bir katkısı da tarihselleştirme (bistoricisation) nosyonu ile ilgilidir. Bourdieu'ye göre rasyonaliteye ilişkin bilimsel ölçütler aşkın gerçeklikler (vérités transcendantales) olmaktan ziyade, belirli biriktirilmiş (kümülatif) entellektüel bir tarihin ürünleriydi. Bu durum da tarihsel olaylara dayanılarak her bir auctor ${ }^{26}$ tara- $^{2}$ fından oluşturulan bilimsel ölçütlerin farklılık gösterebileceğini dikkate alınmasını gerektiriyordu. Bourdieu'ye göre tarihselleştirme kavramını bu şekilde düşünmek, belirlenimci (déterministe) bir bakış açısını mutedil kılmanın yanı sıra, sosyal bilimler alanında mutlakiyetçi tutuma (absolutisme) karşı da güçlü bir panzehir teşkil etmekteydi. Ayrıca Bourdieu'ye göre tarihselleştirme kavramını biriktirilmiş entelektüel bir miras gibi ele almak belirli bir sosyal bağlamdan esinlenip ortaya çıkmalarına neden olan tarihsel ilkelerin doğallaştırılması (naturalisation) ve mutlaklaştırılmasının da engellenmesini mümkün kılmaktayd. Dolayısıyla eleştirel bir perspektiften kabul edilecek bir tarihselleştirme nosyonu doğallaştırma fenomeninin etkilerini etkisiz kılmanın yanı sıra, bilimsel aklın da kendi kendisini kontrol etmesini sağlayabilecekti. ${ }^{27}$

Sonuç olarak Bourdieu’cü yaklaşım, epistemoloji alanında sorgulanmaksızın "var-

Bordeaux, Éditions Le Mascaret, 1986, s.13-14.

22 Bourdieu et.al., Le Métier de Sociologue, s.14.

23 Pierre Bourdieu, Science de la Science et Réflexivité, Paris, Éditions raison d'Agir, 2001, s.15-16.

24 Ibid., s.173-183.

$25 \mathrm{Bu}$ konudaki Bourdieu'cü düşüncenin uluslararası ilişkilere uyarlanması konusunda bkz. Matthew Eagleton-Pierce, "Examining the Case for Reflexivity in International Relations: Insights from Bourdieu”, Journal of Critical Globalization Studies, No.1, 2009, s.111-123.

26 Bourdieu tarafindan kullanılan bu terim bilimsel bir otoriteye işaret etmektedir.

27 Bourdieu, Méditations Pascaliennes, s.135. 
sayılmış" bilgilerin üzerinde durulması gerektiğini, zira bunların habitus'un bir ürünü olabileceğine işaret etmektedir. Bu durum bilgiye yönelik oluşturulan sürecin bir inşa süreci sonucunda ortaya çıktığını ve yeniden sorgulanmasını gerekli kılmaktadır. Durumu Uluslararası İlişkiler kuramlarılla ilişkilendirirsek, Bourdieu’cü düşünsel epistemolojinin Uluslararası İlişkiler disiplinindeki ana akım tabir edilen kuramların epistemolojileriyle uyuşmaz hale geldiğini görmek mümkündür. Zira Guzzini'nin de ifade ettiği gibi pozitivist epistemolojiye sırtını dayayan bu kuramlar genellikle doğa bilimleriyle sosyal bilimleri aynı kefeye koyup analizlerini bu mercek altından gerçekleştirmektedirler. ${ }^{28}$ Oysa Bourdieu'cü düşünsel epistemoloji positivist modelin ampirik olarak test edilmiş ve genel olasılık yasalarından esinlenerek inşa ettiği indirgemeci ve bu yolla da açıklayıcı hipotezlerini yeterli bulmayıp, "nesnelliğin nesnelleştirilmesi” gerektiğinde 1srar etmektedir. Bu durum disiplinde önceden verili bir unsur gibi kabul edilen birçok veri ve kavramın sorgulanmasını gerektirmektedir. Örneğin uluslararası sistemdeki devleti yokdan var olmuş (a-historic) bir unsur gibi kabul etmek ya da onu bilardo topları metaforu ${ }^{29}$ gibi homojen bir şekilde sunmaktansa, tarihselleştirme perspektifinden onun analize dâhil edilmesi sosyolojik olarak heterojen devlet yapılarının karşımıza çıktığını görmemize yardımcı olmaktadır: hukuki anlamda ortak noktaları bulunmakla birlikte bir an için ekonomik kıstasları da bir kenara bırakacak olursak, bu da neden Mali gibi bir devletin toprakları üzerinde egemenliğini tesis edemediğini ve Weberci anlamda meşru güç kullanma tekelini kullanamadığını, aksine neden Almanya gibi bir devletin de Weberci anlamda devletlere has asli özellikleri kendi ulusal toprakları üzerinde etkin bir şekilde uygulayabildiğini anlamamızı sağlamaktadır.

\section{Bourdieu'cü İlişkisel Ontolojinin Uluslararası İlişkiler Kuramlarına Olası Katkiları}

Bourdieu ontoloji konularında sosyal bilimlerde aktörlerin eylemlerinin yapıyı biçimlendirdiğini savunan sübjektivizm ile yapıları ve eyleyenleri soyut bir biçimde sunan (devlet, uluslararası sistem, vs. gibi) "şeyleştirici" (réificateur) pozitivizm arasındaki mevcut iki kutupluluğu reddetmektedir. Bunu aşmak ve mevcut iki kutup arasındaki bağlantıyı kurmak amaciyla da "ilişkisel bir ontoloji" (ontologie relationnelle) önermektedir. ${ }^{30}$ Bunun için de modelin gerçekliği ile gerçekliğin modeli arasında diyalojik bir bağ oluşturulması gerektiğine inanmaktadır. Ve bunu sağlamak için de özellikle eyleyen (agent), habitus, alan (champ) ve illusio gibi kavramlara başvurmaktadır.

28 Stefano Guzzini, "A Reconstruction of Constructivism in International Relations", European Journal of International Relations, Cilt 6, No.2, 2000, s.157.

29 Arnold Wolfers, Discorde and Collaboration: Essay on International Politics, Baltimore, The John Hopkins Press, 1962.

30 Uluslararası ilişkiler disiplini bünyesindeki ontolojik tartışmalar ve özellikle de eyleyen ve yapı konusundaki ayrıntılar için bkz. Colin Wight, Agents, Structures and International RelationsPolitics as Ontology, New York, Cambridge University Press, 2006, s.90-120. 


\section{Aktör Kavramına Karşı Daha Kapsamlı Bir Nosyon: Eyleyen}

Bourdieu eyleyen kavramını nasıl tanımlamaktaydı? Bu kavramın Uluslararası İlişkiler disiplini içerisindeki, özellikle devletleri işaret etmek için kullanılan, aktör kavramından farkı nedir? Aslında Bourdieu rasyonel aktör kavramı ve rasyonalite nosyonuna ilişkin geliştirdiği ayrıntılı argümanlarla yukarıdaki sorulara bazı cevaplar önermenin yanı sıra, eyleyenin ve niteliklerinin nasıl anlaşılması gerektiğini de izah etmektedir. Bourdieu'nün bu konularda özellikle "pratik duyusu" (sens pratique) nosyonun da 1srar ettiğini söylemek mümkündür. ${ }^{31}$ Pratik duyusu nosyonunun özetle Uluslararası İlişkiler disiplinindeki çeşitli kuramsal akımlar tarafından geliştirilen ve günümüzde hala savunucuları bulunan aktörün eyleminin her daim maliyet-hesap ve çıkarların azamiye (maximum) çıkarılması kurgusundan bir takım farkl11ıklar gösterdiğini söyleyebiliriz.

Dolayısıla klasik yaklaşımların geliştirdikleri rasyonalite kurgusundan uzaklaşmak amacıyla Bourdieu eserlerinde eyleyenin özelliklerinin daha belirgin bir şekilde ortaya ç1karılması gerektiğine inanmaktadır. Bunun için öncelikle habitus mekanizmasına başvurmaktadır: bu durum öncelikle bir aktörün salt hesap ve maliyet gibi mekanik bir mantıkla hareket etmeyip davranışlarını rasyonel bir hesabın ürünü olmaksızın da belirli bir amaç doğrultusunda geliştirebileceğini öngörmektedir. Bu bağlam da Bourdieu aktör kavramının yeniden tanımlanması gerektiğine inanmaktadır, zira ona göre mevcut dar aktör tanımlaması eyleyenlerin uygulamalarını açıklamak için yetersiz kalmaktadır. Bu tanımlamayı genişletmek için de ona göre eyleyenlerin davranışlarının belirli bir habitus ün ürünü olduğunun göz önünde tutulması gerekmektedir, çünkü eyleyenler belirli bir sosyal bağlamda bilinçli ya da bilinçsiz bir şekilde bu davranışları içselleştirmişlerdir. Bu durum da belirli bir alan (champ) içerisinde bulunan eyleyenin varlığına ilişkin özelliklerini ve eylemlerini doğrudan etkilemektedir. Aktör kavramının sadece eylem üzerine odaklanması ve eyleyen konusundaki bahsi geçen özellikleri dikkate almaması, Bourdieu’yü sözcük dağarcığını değiştirmeye itip, aktör nosyonundan ziyade eyleyen kavramını tercih etmeye sürükleyecektir.

Peki eyleyenin bir alanda var olup olmadığını nasıl anlayacağız? Bu konuda Bourdieu eyleyenin ancak "etki" yaratabilmesi neticesinde bir alanda var olabileceğini düşünüp, söz konusu etkinin eyleyenin alan dönüştürebilme kapasitesine bağlı olarak düşünülmesi gerektiğini ifade etmekteydi. ${ }^{32}$ Ancak ona göre eyleyenin alan içerisinde olmaması alana etki yapabilme kapasitesini ortadan kaldırmamaktadır. Eyleyenin bir alan içindeki eksikliği veya bu alan içindeki "oyunu” oynamama kararlılığının da söz konusu alan üzerinde dolaylı bir etki yaratabileceğini akılda tutmanın gerekli olduğunu düşünmektedir. Bunların yanı sıra Bourdieu'ye göre bir alan içinde bir eyleyen tarafindan güç dengeleri değiştirildiğinde, düzenin normlarını elinde bulunduranlar "oyundan" safdışı olabilmektedir. ${ }^{33}$

31 Pratik duyusu ile ilgili ayrıntılı bilgi için bkz. Pierre Bourdieu, Le Sens Pratique, Paris, Éditions de Minuit, 1980.

32 Pierre Bourdieu, Propos sur le Champ Politique- avec une introduction de Philippe Fritsch, Lyon, Presses Universitaires de Lyon, 2000, s.38-61.

33 Ibid., s.62. 
Eyleyenin alanla ilişkisi konusunda ise, Bourdieu alanın evrimsel ve dinamik niteliklere sahip olduğunu, eyleyenlerle bu alana yeni girenler arasındaki güç ilişkilerine bağlı olarak alanın dönüşebileceğini ifade etmektedir. Bu durum da sosyal doku (saha) eyleyenlerin aralarındaki taahhütlerine bağlı olarak yeni özellikler ihtiva ederek kendini yeniden üretebilmektedir. ${ }^{34}$

\section{Yapının Rijit Kalıplarından Çıkısın Yolu: Habitus}

Habitus kavramı her ne kadar Pierre Bourdieu tarafından geliştirilmese de kendisi bu eski aristocu-tomist kavramı yapı/eyleyen ikileminden çıkarmak amacıyla yeniden geliştirmiştir. ${ }^{35}$ Bunun için de Saint-Thomas d'Aquin, Emile Durkheim, Norbert Elias, Marcel Mauss ve Max Weber gibi isimlerden esinlenmiştir. ${ }^{36}$ Habitus kavramı ilk ortaya çıktı̆̆1 anda ${ }^{37}$ aktörlere hiçbir kabiliyet manevrası bırakmıyordu, zira aktörün sosyal dünyanın yapılarından etkilendiği ve edilgen bir konumda olduğu düşünülüyordu. ${ }^{38}$ Daha sonra bu kavramın içeriğini Bourdieu gitgide geliştirip habitus kavramını "eylem, değerlendirme yetisi ve alg1 matrisleri gibi her an işleyen ve bünyesine geçmiş tecrübeleri de dâhil eden, kalıcı ve yeniden üretilebilir düzenlemeler sistemine" işaret etmek için kullanacaktır. ${ }^{39}$ Nihayet determinist düşünceden ve daha önce yapıya atfettiği önemden sıyrılmak için, eyleyenlerin eylem kapasitesini ve yapıyı yapılandırma gücünü de dahil edip, sosyal dünya içinde eyleyenleri de etken bir birim olarak kabul edecektir. ${ }^{40}$ Böylece Champagne ve Christin'in de ifade ettiği gibi bu durum Bourdieu'yü "eylem ve yapılar, nesnel koşul ve bireysel stratejiler arasındaki ilişkileri dikkate alabilecek bir praksoloji (eylemler kuramı) oluşturabilmek için uygulamayı/eylemi içselliğin dışsallaştırıldığı ve dışsallığın içselleştirildiği diyalektik bir saha" olarak görmeye itecektir. ${ }^{41} \mathrm{Bu}$ yolla da "mekanik kuram savunucularının" yapıya atfettiği önemden bir nebze olsun sıyrilabildiğini düşünecektir. ${ }^{42}$ Netice de Bourdieu’de makro-sosyal yapıyla mikro-davranışsal eylemler arasındaki ilişkiyi gözle görünür kılıp, yapı ve eyleyenin birbirlerini yapan ve yapilandıran (structurant/structuré) öğeler olduğunu savunacaktır. ${ }^{43}$

34 Bourdieu, Méditations Pascaliennes, s.195.

35 Bourdieu, Choses Dites, s.20.

36 Anne Jourdain ve Sidonie Naulin (der.), La Théorie de Pierre Bourdieu et Ses Usages Sociologiques, Paris, Armand Colin, 2011, s.35. Makalede zikredilen unsurlar dışında Weberci düşüncenin Pierre Bourdieu üzerindeki diğer etkileri için ayrıca bkz. Rogers Brubaker, "Rethinking Classical Theory: The Sociological Vision of Pierre Bourdieu”, Theory and Society, Cilt 14, 1985, s.745-775.

37 Pierre Bourdieu ve Jean-Claude Passeron, La Reproduction. Éléments pour une Théorie du Système d'Enseignement, Paris, Minuit, 1970.

38 Anne Jourdain ve Sidonie Naulin (der.), La théorie de Pierre Bourdieu et Ses Usages Sociologiques, s. 37.

39 Bourdieu, Esquisse d'une Théorie, s.261-262.

40 Bourdieu, Choses Dites, s.156.

41 Patrick Champagne ve Olivier Christin, Pierre Bourdieu- Une initiation, Lyon, Presses Universitaires de Lyon, 2012, s.71.

42 Bourdieu, Esquisse d'une Théorie, s. 262.

43 Laurent Thévenot, "Pragmatic Regimes Governing The Engagement With The World", Theodore R. Schatzki et.al., The Practice Turn in Contemporary Theory, New York, Routledge, 2001, s.66. 


\section{Alan Kavramı: Eyleyenlerin Eylemlerinin Çok Boyutlu Bir Düzlemde Analize Dahil Edilmesi}

Alan kavramının herşeyden önce niteliklerini betimleyecek olursak, Bourdieu bunun mücadelelerin varlığ1 üzerine kurulu bir düzen olduğunu belirtmektedir. Bu mücadelelerin kurulu düzene giriş hakkını elde etmeye çalı̧san yeni "oyuncularla" bu düzendeki güç ve iktidar tekelini elinde tutmaya ve yeni "oyuncuları" rekabetin dışına itmeye çalışan "baskın (dominant) oyuncu veya oyuncular" arasında cereyan ettiğini söylemek mümkün. Bourdieu'ye göre, bu mücadeleler belirli bir amacı (maddi veya sembolik) elde etmek için gerçekleşmektedir. Bu bağlamda, alanın yapısı ve karakteristikleri, daha önceki mücadelelerin neticesinde biriktirilmiş belirli bir kapitalin (maddi veya sembolik) dağıtımı için mücadeleye girişmiş eyleyenler veya kurumlar arasındaki güç ilişkisi olarak betimlenmektedir. Bourdieu'ye göre, alan bünyesinde oyunu oynayanların ortak noktası alanın varlığını sürdürebilmesinden başka birşey değildir, dolayısıyla alandaki belirli bir oyunu oynamak alanın üzerine inşa edildiği değerlerin tüm eyleyenler tarafından karşılıklı olarak tanınması anlamına gelmektedir. ${ }^{44} \mathrm{Bu}$ durum baskın oyuncularla yeni oyuncuların alanın üzerine inşa edildiği değerlerin yeniden üretilmesini sağlamaktadır. Başka bir deyişle Bourdieu'cü analizde alana dâhil olmaya çalışan yeni oyuncular alanın "varlığını" tehdit etmemektedir.

$\mathrm{Bu}$ genel ifadelerden yola çıkarak özetle bir alanın niteliklerini şu şekilde bir araya getirmek mümkün: alan içerisinde eyleyenlerin var olduğu; bunların oynamaya hazır oldukları bir oyun; alan içerisinde mevcut güç/iktidar ilişkilerinin varlığı; alan içerisinde mücadeleye konu olacak unsurların (maddi veya sembolik) varlığ 1 ve nihayet eyleyenler tarafından kabul edilen ve alandaki oyunun sürdürülmesini mümkün kılan kuralların varlığı. Forget ve Rayroux ise bunu "pozisyonlarını iyileştirmeyi stratejik amaç edinip, belirli kurallar dâhilinde, etkileşimde bulunan aktörler arasındaki güç ilişkileri” olarak özetlemektedir. ${ }^{45}$ Bunların yanı sıra, alan içerisinde eyleyenler kendi aralarındaki ilişkileri düzenlemek için çesitli kapitallerle donatılmışlardır (ekonomik, sembolik, sosyal ve kültürel). Bu bağlamda bir unsurun göreceli değeri ilişkilerin tümü tarafından belirlenmektedir. Dolayısıyla Kauppi’nin de ifade ettiği gibi alan kavramı siyasi partilerden tutun uluslararası örgütlere ve ulus-devletlere kadar bir dizi birimi (veya eyleyeni) bir alan olarak incelebilmeyi mümkün kılmaktadır. ${ }^{46}$ Netice de Rebecca Adler-Nissen'in de ifade edeceği gibi yapının özelliklerini anarşik olarak betimleyen ana akım kuramcıların aksine, Bourdieu'cü okuma bunun hiyerarşik olduğu sonucuna varacaktır ${ }^{47}$, buradaki hiyerarşi haliyle eyleyenlerin ellerinde bulundurdukları maddi ve maddi olmayan kapitallerin sonucuna göre belirecektir.

44 Pierre Bourdieu, Questions de Sociologie, Paris, Éditions de Minuit, 2002, s.113-120.

45 Amélie Forget ve Antoine Rayroux, "Introduction: La Sécurité Européenne et le Tournant Pratique des Relations Internationales", Études internationales, Cilt 43, No.4, 2012, s.508.

46 Niilo Kauppi, "Bourdieu's Political Sociology and the Politics of European Integration", Theory and Society, Cilt 32, No.5/6, 2003, s.778.

47 Rebecca Adler-Nissen, "Inter and Transnational Field(s) of Power- On a Field Trip With Bourdieu", International Political Sociology, Cilt 5, No.3, 2011, s.327. 
Bunların yanı sıra Bourdieu belirli bir alanda ortaya çıkan güç mücadelesinin diğer alanlarda beliren güç mücadelelerinden de farklılık arz edeceğinin altını çizmektedir. ${ }^{48}$ Ancak farklı alanların bulunması bu alanlar arasında bir kopukluğun olduğu anlamına gelmemektedir. Bu durum belirli bir Leviathan'ın var olmadığ 1 anarşik olarak kabul edilen bir alandaki eyleyenler arasındaki (inter-state level) oyunun özelliklerini Weberci anlamda meşru şiddet kullanma tekeline sahip bir eyleyenin kendi ulusal sınırlarında bulunan (infra-state level) diğer eyleyenlerle oynayabileceği oyunun özelliklerinden farklı olduğunu savunan ana akım kuramcıların aksine ulusaşan düzeyin dikkate alınması gerektiğini ve bu seviyede de güç mücadelelerinin ortaya çıkabileceğini öngörmektedir. Rebecca AdlerNissen’in de saptadığı üzere bu tür katı ikiliklerin (ulusal/uluslararası) geçersiz olduğunu görmek ve ulusaşan seviyedeki güç alanlarının da tesis edilebileceğini saptamak için merceğin Avrupa Birliği bünyesindeki çeşitli kurumlara yönetilmesi yeterlidir. ${ }^{49}$

Alanın diğer bir özelliği de uzun bir inşa sürecinde evrim geçirebileceğinin analiz de dikkate alınmasıdır, böylece alan içerisindeki gerek uygulamalar gerekse bu uygulamalar ışı̆̆ında inşa edilmiş düşünce ve kavramların köklerine (aspect généalogique inilebilmektedir. ${ }^{50} \mathrm{Bu}$ durum da Uluslararası İlişkiler kuramlarında sorgulanmaksızın otomatik (automatisation) bir refleksle kullanılan (egemenlik, devlet, uluslararası sistem gibi) nosyonların inşa edilme süreçlerinin daha kapsamlı bir şekilde anlaşılmasına yardımcı olmaktadır.

\section{Homooeconomicus'tan Homosociologicus'a Geçiş: Illusio'nun Önemi}

Özetle "oyuna dâhil olmak, oyunu oynamaya eğilimli olmak ve nihayet oyunu ciddiye almak" olarak Bourdieu tarafindan tanımlanan illusio kavram $1^{51}$, ayrıca Accardo'nun da ifade ettiği gibi belirli bir alan içinde eyleyenlerin konumunun değiştirilmesi veya bunun diğer eyleyenlerin baskılarına rağmen muhafaza edilmesini de kapsamaktadır. ${ }^{52}$ Bunların yanı sıra illusio kavramı alanı bir oyun sahası olarak görüp, eyleyenlerin eylem ve düşüncelerinin bu alan içerisinde etkiye ve değişime açık olabileceğini de varsaymaktadır. ${ }^{53}$ Eyleyenler arasında fiziksel bir ilişkinin hesap ve maliyet kurgusunu kurabilmek için zorunlu bir durum olarak kabul edildiği rasyonalist paradigmanın aksine, Bourdieu'cü analizde illusio

48 Pierre Bourdieu, Propos sur le Champ Politique, s.40. Pierre Bourdieu'nün baskınlık (domination), iktidar/güç, sembolik şiddet gibi kavramları ne şekilde anladığına yönelik ayrıntılı bir çalı̧̧ma için bkz. Lahouari Addi, "Violence Symbolique et Statut du Politique chez Pierre Bourdieu", Revue Française de Science Politique, No.6, 2001, s.949-963.

49 Rebecca Adler-Nissen, "The State's Symbolic Power and Transnational Fields", Rebecca AdlerNissen (der.), Bourdieu in International Relations-Rethinking Key Concepts in IR, s.179-192. Güvenlik alanında ulusaşan seviyedeki bu tür güç mücadeleleri için ayrıca bkz. Didier Bigo, "L'Europe de la Sécurité Intérieure Penser Autrement la Sécurité, Anne-Marie le Gloannec (der.), Entre Union et Nations, Paris, Presses de Sciences Po., 1998, s.55-90.

50 Bourdieu, Propos sur le Champ Politique, s.51-53.

51 Pierre Bourdieu, Raisons pratiques. Sur la Théorie de l'Action, Paris, Éditions du Seuil, 1994, s.151.

52 Alain Accardo, Introduction à une Sociologie Critique- Lire Bourdieu, Bordeaux, Editions le Mascaret, 1997, s.102.

53 Bourdieu, Méditations Pascaliennes, s.196-197. 
eyleyenlerin bilişsel ve eyleme değin repertuarlarının harekete geçirilebilmesi için fiziksel bir ilişkiyi zorunlu kılmamaktadır.

Bunlara ilaveten, illusio'nun rasyonalist paradigmanın çıkar kavramından bir başka farklılığı da, bunun hesap ve maliyet dışındaki sosyal oyunları da tanımına dâhil etmesidir. Diğer bir faklılık da, çıkar kavramının özü ile ilgilidir. Bilindiği gibi rasyonalist paradigma da aktörlerin varoluşsal nedenlerden dolayı çıkar gütmeme gibi bir "lüksleri” yoktur ve aktörler sürekli bu dürtüyle eylemlerini kurgularlar, oysaki illusio kavramında eyleyenlerin oynanan oyuna mesafeli kalabileceği kabul edilmektedir. ${ }^{54}$

Bourdieu çıkar kavramından ziyade illusio'yu kullandığında, bu aslında eyleyenlerin ekonomik kazançlar dışında, belirli bir alanda eyleyenlerin sembolik unsurlarını da diğer eyleyenlere kabul ettirmeye yönelik girişmiş oldukları çabalara işaret etmektedir. $\mathrm{Bu}$ açıklamalardan da anlaşılabileceği gibi Bourdieu homooeconomicus'cu bakış açısını eyleyenleri her daim rasyonel bir şekilde eylemlerini ve amaçlarını hesap ederek bunların neticesinde minimum maliyetle maksimum kazanç elde edeceğini varsaydığı için, ayrıca eyleyenlerin güdülerini salt ekonomik çıkarlara indirgediği için reddetmektedir. ${ }^{55}$ Haliyle homooeconomicus'cu mantıkla eyleyenlerin güdülerini anlamaya kalkıştığımızda kaçınılmaz olarak ekonomik alandaki kuralların diğer alanlar içinde geçerli olabileceğini varsaymış oluruz, oysaki alanlar arasındaki hem güç mücadeleleri hem de eyleyenlerin güdüleri alanların yapısındaki ve doğasındaki değişikliklerden ötürü farklılık arz edebilmektedir.

Rasyonalist paradigmalardan farklı olarak Bourdieu'nün sosyolojik yaklaşımı ayrıca eyleyenin belirli bir topluluğa/gruba aidiyetini de hesaba katmaktadır, böylece eyleyenin eylemleri hem ait olduğu topluluğun/grubun hem de kendisinin zorunluluklar1/ yükümlülükleri tarafindan belirlenebilmektedir. Dolayısıyla eyleyen rasyonel davranışı için bir manevra kabiliyetine sahip olsa bile, kendisi ne yoktan var olmuştur ne de gruptan izole bir birim olarak varlığını sürdürmektedir. Bu durum da eyleyenin var olduğu sosyal dokunun kural ve zorunluluklarının dikkate alınmasını gerektirmektedir. Böylece eyleyenin sınırlı bir rasyonalitesinin olduğu ve bunun belirli bir grup/topluluktan gelen diş dinamiklerce koşullandırılabileceği kabul edilmektedir. Ayrıca, rasyonalist paradigmalar belirli bir saha içinde jenerik olarak oluşturulan rasyonel aktörün "hamle ve karşı hamle” doğrultusunda hareket ettiğini varsaymaktadırlar. Oysa Bourdieu eyleyenin belirli bir sosyal doku içerisinde oluşturulan kural ve normlar çerçevesinde hareket ettiğini savunmaktadır. O iktisatçıların jenerik, tarihten arındırılmış (a-historique) ve doğal bir unsur gibi kabul ettiği çıkar kavramının aksine, bunun herşeyden önce habitus'ün düzenlemeleri tarafindan belirlendiğine inanmaktadır. Bu nedenle de "her ampirik örnek olayda söz konusu çıkarların ve onların içeriklerinin üretildiği sosyal koşulların ortaya çıkarılması" gerektiğine inanmaktadır. ${ }^{56}$

54 Bourdieu, Raisons pratiques., s.151-152.

55 Ibid., s. 154.

56 Bourdieu, Les Choses Dites, s.62-63. 


\section{Bourdieu Sosyolojisi Prizmasından Uluslararası İlişkileri Yeniden Okumak}

Bourdieu'cü perspektiften epistemolojik ve ontolojik sorunlar irdeledikten sonra şimdi de onun araştırmalarında sık sık başvurduğu bazı anahtar kavramlara odaklanarak bu mercekten uluslararası ilişkileri nasıl okuyabileceğimizi görelim. Bunun için de öncelikle eyleyen kavramından başlayalım. Bourdieu eyleyenin belirli bir alan (champ) içindeki varoluşunu (ya da analize dâhil edilebilmesini) onun yaratabileceği etki kapasitesine göre dikkate almaktadır. ${ }^{57}$ Ancak bu yaklaşım tarzı bazı sorunları da beraberinde getirmektedir. Bourdieu "etki üretmeyle" tam olarak neyi anladığını ayrıntılı bir şekilde izah etmemesinin yanı sıra, eyleyenlerin salt etki etme gücüne odaklanarak eyleyenlerin geçirebilecekleri "radikal değişimleri" de gözden kaçırmaktadır. Bu durum da belirli bir sosyal doku içinde herhangi bir ayrıcalığı olmayan "eyleyen" minimum "etki üreten" bir birim olarak karş1mıza çıkmaktadır. Örneğin uluslararası sistem de çeşitli nedenlerden dolayı "ekonomik olarak az gelişmiş" yaftası yapıştırılan bir ülke sistem de "etki üretme" potansiyeli olarak düşük değerlendirilmek zorundadır. Oysa yapısal ve konjonktürel zorluklar yaşadığı için "geri kalmış" olarak nitelendirilen bir devlet içindeki iç dinamikler hızla ulusal ölçekten bölgesel ve küresel ölçeğe kayıp uluslararası sistemde kriz yaratabilmektedir. Somali, Afganistan, Mali ve son olarak Suriye'de yaşanan gelişmeler buna güzel bir örnek teşkil etmektedir. Bu devletler son dönemdeki krizler öncesinde "etki üretme" gücü olarak yapıy1 şekillendirebilecek unsurlar olarak değerlendirilmezken, krizler patlak verdiğinden bu yana yaşadıkları "istikrarsızlıklardan" dolayı yapı içindeki güç dengelerini ciddi şekilde etkiler mahiyet kazanmışlardır. ${ }^{58}$ Dolayısıyla uluslararası siyasette herhangi bir ayrıcalığı olmayan eyleyenler de çeşitli alanların içiçe geçtiği küreselleşen bir dünya da yapının kendisini çeşitli yollarla etkileyebilme potansiyeline sahiptirler.

Ya da mikro-politik düzeyde 11 Eylül 2001 olaylarının da gösterdiği gibi "sade" vatandaş ya da birey olarak değerlendirilen bir eyleyen belirli inançlar doğrultusunda ya da bir çlğınlığın neticesinde bir intihar komandosuna dönüşüp uluslararası siyaset gibi belirli bir alanda veya birbiriyle ilişkili bir dizi alanlarda (champs) (ekonomik, siyasi ve kültürel gibi) tahrip edici "etkiler" üretip "mimimun etki üretme" eşiğinden çok kısa bir sürede "maksimum etki üretme" eşiğine de ulaşabilmektedir. Dolayısıyla eyleyenleri "etki üretme" güçlerinden yola çıkarak gerçekleştirilecek olası bir tasnifleme onların belirli bir alan veya alanlara "etki etme" kapasitesilerini statik bir vizyona indirgemektedir. Netice de eyleyenlerin etki üretme gücünde doğacak ani değişimler ve bunların hızlı bir şekilde alanı dönüştürme kapasitesine Bourdieu’cü analizde değinilmemektedir.

Eyleyen ile ilgili diğer bir unsur da "kimin", "kimi” eyleyen olarak belirleyeceğiyle ilgilidir. Kim eyleyeni belirleme "meşruiyetine" sahiptir? Kim hangi eyleyeni belirli bir alan da kabul etme yetkisini elinde bulundurmaktadır? Bu konulara da açıklık getirilmemektedir. Bourdieu ayrıca belirli bir alan da eyleyenler arasında rekabetin ve güce dayalı bir ilişkinin varlığının altını çizmektedir, bu durum da oyuna dâhil olan "yeni” eyleyenin

57 Bourdieu, Propos sur le Champ Politique, s.38-61.

58 Bu tür devletlerin yapıda ne tür sorun yaratabilecekleri konusunda bkz. Robert I. Rotberg (der.), When State Fail: Causes and Consequences, New Jersey, Princeton University Press, 2004. 
belirli bir alana girerken buradaki mevcut eyleyenlerle çatı̧macı bir ilişkiye gireceği varsayılmaktadır. Ancak yeni eyleyen alana materyel (askeri gibi) ya da sembolik gücünü, diğer bir ifadeyle soft power' $1 \mathrm{n}$ kullanarak mı dâhil olmaktadır? Bourdieu bu konularda sadece bir "alan içinde bir eyleyen tarafından güç dengeleri değiştirildiğinde, düzenin normlarını elinde bulunduranların aniden safdışı bırakılacağına" 59 işaret etmektedir, oysa bu durum bazı sorunları da beraberinde getirmektedir. Çünkü alanda baskın (dominant) role sahip eyleyenlerin alana yeni giren eyleyenlerle aralarında güç kullanımı olmaksızın baskın rolün teslim edilebileceği olasılığı gözden kaçırılmaktadır. Hegemonik gücün güç kullan1mı olmaksızın devri konusunda İkinci Dünya Savaşı öncesi dönem örnek verilebilir. Bu dönemde hegemonik gücü elinde bulunduran Büyük Britanya ile uluslararası sisteme bu savaştan sonra hegemonik güç olarak girecek $\mathrm{ABD}$ arasında, diğer bir deyimle hegemonik gücü elinde bulunduranla bu gücü elde etmeye çalışan yeni eyleyen arasında, rol değişimi konusunda bir güç kullanımı olmamı̧̧ır. Aksine iki eyleyen İkinci Dünya Savaşı süresince müttefik olarak dünya-sisteminde güç hiyerarşisini alt üst etmeye hevesli Nazi Almanya’sına karşı birlikte mücadele vermişlerdir. Ve hegemonik rol konusundaki devir teslim işlemi gerçekleştikten sonra da Büyük Britanya'nın uluslararası sistem içindeki ne önemi azalmıştır ne de eski hegemonik güç olarak kendisi safdışına bırakılmıştır. Büyük Britanya'nın Birleşmis Milletler Güvenlik Konseyi daimi üyeliği vasıtasıyla güncel uluslararası sorunlar konusunda oynadığı rol de bunu göstermiştir. Bu konuyla ilgili İspanya, Fransa, Hollanda gibi tarih içinde uluslararası sistemde başat rol oynamış ve sonrasında orta ölçekli bölgesel güç kategorisini kabul etmiş devletlerin örneği de ilave edilebilir.

Bu tür eksikliklere karşın, Bourdieu'cü okuma belirli bir alanın evrimsel ve dinamik niteliklere sahip olup başat eyleyenlerle bu alana yeni girenler arasındaki güç ilişkisine bağlı olarak alanın dönüşebileceğini analizine dâhil etmesiyle uluslararası sistemi statik bir mekân olarak betimleyen uluslararası ilişkiler kuramındaki bazı paradigmaların bu konuyla ilgili eksikliklerini de gidermektedir. Alanı (uluslararası sistem gibi) dinamik bir mekân olarak görmek, modern devletlerin doğuşunu hızlandıran Vestfalya antlaşmalarından bu yana ne ölçüde uluslararası sistemin ve devlet-eyleyenlerin değişim geçirdiğini anlamamıza yardımcı olmaktadır. ${ }^{60}$ Bilindiği gibi Vestfalyen dönemin başlangıcında uluslararası sistem içinde devlet-eyleyenler baskın bir rol oynayıp, sistem içinde oyunun kurallarını aralarındaki etkileşimlerin sonucuna göre belirlemişlerdir. Oysa Post-Vestfalyen dönemde uluslararası ilişkilerdeki oyunun kurallarının salt devletlerarası ilişkiler tarafından belirlendiğini iddia etmek bugün oldukça güçtür. Dolayısıyla devlet-eyleyenler PostVestfalyen dönemde uluslararası siyaseti uluslararası örgütleri, hükümetdışı kuruluşları, uluslararası yasadı̧̧ kartelleri ve çokuluslu şirketleri de dikkate alarak artık belirlemek durumundadırlar. Ve Post-Vestfalyen dönemin özellikleri Vestfalyen dönemin özelliklerinden ne kadar farkl1lik gösteriyorsa, Vestfalyen döneminkiler de modern devletlerin oluşumlarını henüz tamamlamadığı ve sadece eyleyen olarak derebeylik, imparatorluk ve

59 Bourdieu, Propos sur le Champ Politique, s.62.

60 Devletin statik bir unsur olmadığı ve uzun tarihsel bir süreçte farklı dinamiklerin etkisinde her defasında yeniden inşa edildiğini incelemek için bkz. Jens Bartelson, The Critique of The State, New York, Cambridge University Press, 2003. 
krallıkların sistemde bulunduğu Vestfalyen öncesi (pré-Westphalien) döneminkilerden bir o kadar farkllilk göstermektedir. ${ }^{61}$

Bu bağlamda alanın dönüşümüyle birlikte devletlere has özelliklerde de bir takım değişikler meydana geldiğini saptamak mümkün. Bunun en açık göstergesini egemenlik unsurun da görebiliriz. Bu bağlamda de jure olarak olmasa da sosyolojik olarak uzun bir tarihsel süreçte egemenliğin sosyal bir olgu olarak ne tür bir evrim geçirdiğini görmek mümkün ${ }^{62}$, zira Anna Leander'in de ifade ettiğgi gibi egemenliği statik bir unsur gibi ele almak, egemenliğin tesis edildiği alanlardaki özelleştirmeleri görmezden gelmek anlamına gelebilir. ${ }^{63}$ Oysa bugün devlet-eyleyenler egemenliklerini bazen hükümetdışı aktörlere regalyen alanlarda dahi devretmektedirler.

Bunların dışında Bourdieu'nün eyleyen nosyonu literatüre hâkim paradigmalar tarafından sık bir şekilde kullanıllan "rasyonel aktör" kavramının sı̆̆ içeriğini de zenginleştirmektedir. Burada Bourdieu ilişkisel ontolojiden yararlanarak eyleyenlerin varlıklarına odaklanmaktansa eylemlerini dikkate almaktadır. Böylece eyleyen kavramı bir yandan sosyal dokunun (uluslarararasi, ulusal ve yerel ölçekteki) eyleyen üzerindeki etkisini analize dahil ederken, eşzamanlı olarak da eyleyenin bu dokuya etki etme kapasitesini dikkate alıp mekanla eyleyen arasındaki bu yinelemeli (itérative) diyalektik ilişkinin belirli bir $b a-$ bitus kapsamında tesis edildiğini iddia etmektedir. Netice de eyleyenler ne salt devletlere indirgenmiş olmakta ne de eyleyenlerin eylemleri, Gerçekçi ve liberal kuramlarda olduğu gibi, sadece uluslararası ilişkiler alanıyla sınırlandırılmaktadır.

$\mathrm{Bu}$ son nokta doğal olarak bizi Bourdieu'nün devlet eyleyeni nasıl algıladığı ve onu analizlerine nasıl dâhil ettiği konusuna getirmektedir. Pierre Bourdieu analizlerin de devlete özel bir önem atfetmiştir ${ }^{64}$, bunun başlıca nedeni devlet-eyleyenin güç alanında merkezi ve ayrıcalıklı konuma sahip olmasıdır, zira devlet maddi ve maddi olmayan ${ }^{65} \mathrm{ka}-$ pitaller üzerinde monopolü elinde bulunduran yegâne güçtür. Bu bağlamda Bourdieu'nün güç kavramına dayanarak devlet yapılarıyla ilgili yapmış olduğu sınıflandırmayı hatırlatmakta fayda var. Bu durum Weberci anlamda rasyonalizasyon sürecini tamamlamamış devlet eyleyenleriyle aksine bu süreci tamamlamamış olanlar arasındaki farkın da ortaya

61 Vestfalyen ve Vestfalyen öncesi dönem arasındaki farklar için örneğin bkz. Jeremy Larkins, From Hierarchy to Anarchy- Territory and Politics Before Westphalia, New York, Palgrave MacMillan, 2010.

62 Ulusal eğemenliğin tesis edilişi ve tarihsel süreçte dönüşümü konusunda ayrıntılı bir inceleme için bkz. Jens Bartelson, $A$ Genealogy of Sovereignty, New York, Cambridge University Press, 1995.

63 Anna Leander, "Securing Sovereignty by Governing Security Markets”, Rebecca Adler-Nissen ve Thomas Gammeltoft-Hansen (der.), Sovereignty Games- Instrumentalizing State Sovereignty in Europe and Beyond, New York, Palgrave Macmilan, 2008, s.158.

64 Bourdieu'nün devlet konusundaki görüşlerini ayrıntılı bir şekilde incelemek için bkz. Pierre Bourdieu, Sur l'État-Cours Au Collège de France 1989-1992, Paris, Raisons d'Agir/Seuil, 2012; Pierre Bourdieu, "Rethinking the State: Genesis and Structure of Bureaucratic Field", Sociological Theory, Cilt 12, No.1, 1994, s.1-18.

65 Bourdieu'nün maddi olmayan kapitalleri nasıl anladığını ayrıntılı bir şekilde incelemek için bkz. Pierre Bourdieu, Langage et Pouvoir Symbolique, Paris, Éditions du Seuil, 2001. 
çıkmasına yardımcı olacaktır. Ona göre, geleneksel toplumlarda iktidar/güç bireysel olup yeniden türetilmesi ailevi temellere dayanmaktadır, oysa toplumsal farklılaşmanın (société différenciées) gerçekleştiği yapılarda başatlığın (domination) icra edilişi devlet kurumlar1 tarafindan gerçekleştirilmektedir. ${ }^{66} \mathrm{Bu}$ yönüyle Bourdieu devletin kurumsallaşmasına verdiği önemden ötürü ve başatllk konusundaki tasniflemeyle Weberci sosyolojiye çok yaklaşmaktadır. ${ }^{67}$ Devleti ve onun bünyesinde icra edilen güç unsurunu anlamaya yönelik Bourdieu tarafindan yapılan bu sınıflandırma aslında çok önemli diğer bir noktaya da vurgu yapmaktadır. $\mathrm{O}$ da uluslararası sistem de var olan tüm devlet-eyleyenlerin her ne kadar de jure bir tanımlamayla ortak noktaları olsa da aslında sosyolojik olarak bu devleteyleyenlerin birbirlerinden, devlet aygıtının rasyonalizasyon süreci ve bunun sonucunda maddi ve sembolik kapitaller üzerinde sahip olunan monopoller gibi, farkl1lık gösterdikleriyle ilgilidir. ${ }^{68}$

Ayrıca devlet aygitının oluşumunun $и z u n$ bir tarihsel süreçte eyleyenlerin kendi bünyelerinde verdikleri mücadelelerin sonucunda orta çıkmasına işaret etmesiyle Bourdieu bu açıdan da Norbert Elias'ın devletle ilgili düşüncelerine çok yaklaşmaktadır. ${ }^{69}$ Dolayısıyla Bourdieu uluslararası arena da sadece çıkar dürtüsüyle hareket ettiğini varsayıp devletin tarihsel boyutunu göz ardı eden ana akım kuramların devlet tipolojisinden uzaklaşmaktadır. Oysa uluslararası sistem de devlet incelenirken analizlerde onun tarihsel gelişiminin akılda tutulması söz konusu devletin ortaya çıkmasına sebeb olan güç alanım (champ de pouvoir) ve bu alandaki eyleyenleri ve onların ellerinde bulundurdukları kapitalleri anlamamızı sağlamaktadır. Ancak burada dikkat edilmesi gereken bir unsur Bourdieu'nün devleti düşünürken, Norbert Elias örneğinde olduğu gibi, daha ziyade Batı'daki ortaya çıkmış devlet mekanizmalarından esinlenmiş olmasıdır. Diğer bir deyişle Bourdieu devlet aygıtının işlemez olduğu ve bu aygıtın devlet dışı eyleyenler tarafindan "ele geçirildiği" durumlara değinmemektedir. Bilindiği gibi, uluslararası sistem de Kolombiya, Arnavutluk veya Afrika kıtasındaki birçok devlet örneğin de olduğu gibi bazı devlet-eyleyenler devlet dışı eyleyenler tarafindan "kontrol altına" alındığında devlet mekanizması Weberci anlamdaki meşru gücün tekelini, de jure olarak elinde bulundursa bilse, gerçekte bunu uygulamakta güçlük çekmektedir. ${ }^{70}$ Ve Bourdieu, Elias örneğin de olduğu gibi bu durumu görmezden gelmektedir. Devletle ilgili diğer bir unsur da Bourdieu'nün devleti nüfûz/hâkimiyet mücadelesinin gerçekleştiği bir "mekân” olarak tanımlamasıyla ilgilidir. Söz konusu "mekân" da var olan eyleyenlerin niyetleri ve etkileşimlerinin (ilişkisel

66 Pierre Bourdieu, "Les Modes de Domination", Actes de la Recherche en Sciences Sociales, Cilt 2, No.2/3, 1976, s.122-132.

67 Max Weber'in devletle ilgili ayrıntılı görüşleri için bkz. Max Weber, Économie et Société- birinci ve ikinci ciltler, Paris, Plon, 1971.

68 Devletler arasındaki sosyolojik farklılıklar konusunda ayrıntılı bir çalışma için bkz. Bertrand Badie ve Pierre Birnbaum, Sociologie de l'État, Paris, Grasset, 1979.

69 Norbert Elias'in Batı'da devletlerin oluşumuyla ilgili düşünceleri için bkz. Norbert Elias, $L a$ Dynamique de l'Occident, Paris, Pocket Collection Agora, 1990.

70 Robert H. Jackson, Quasi-States: Sovereignty, International Relations and the Third World, Cambridge, Cambridge University Press, 1996. Bu konuyla ilgili daha genel bir çalışma için bkz. Béatrice Hibou (der.), La Privatisation des États, Paris, Karthala, 1999. 
anlamda) yanı sıra buradaki konuşlandırılan gücün doğası da daha geniş bir yelpazeden incelenerek, böylece bu "mekân" da eyleyenler tarafından konuşlandırılan tüm kapitaller (maddi ve manevi) ortaya çıkarılmaya çalışılmaktadır. Bu tür bir devlet tanımlaması uluslararası ilişkiler literatüründeki bazı kuramların jenerik devlet mantığından haliyle farklılık göstermektedir.

Alan ve habitus kavramlarının disipline ne gibi katkılar getirdiğine göz atacak olursak, öncelikle Bourdieu'nün ne alanların ortaya çıkmasını tetikleyen koşulları ne de belirli bir alanın inşa sürecinin hangi evrelerden geçtiğine değinmediğini hatırlatmak da fayda var. Alan konusunda ona göre önemli olan belirli bir sosyal dokuda eyleyenlerin etkileşimlerinden yola çıkarak etki üretme kapasitelerinin alanın evrim sürecini nasıl etkilediğini incelemektedir. Burada vurgunun doğrudan eyleyenlere yapılmaktansa aralarındaki ilişkilerin doğasına yapıldığını görmek mümkün. Bourdieu bu çerçeve de eyleyenler arasındaki ilişkilerin doğasını inceleyip, bunların arasındaki maddi ve sembolik kaynakların ne şekilde ve kim tarafından dağıtıldığını anlamaya çalışmıştır. Bu yöntemle belirli bir alan içinde hem pozisyonlar, hem ilişkilerin doğası hem de eyleyenlerin tercih ettiği uygulamalar gün ışığına çıkarılmaya çalışılmaktadır. Bu durum hem yapıya öncelik vererek bunların eyleyenlerin dünyasındaki "anlamları" inşa ettiğini iddia eden ana akım kuramlarla, hem de kendisinin de ifade ettiği gibi eyleyenlerin eylem ve niyetlerini tam bir rasyonalite dâhilinde gerçekleştirdiklerini iddia eden sübjektivist yaklaşımlardan farklılık göstermektedir. ${ }^{71}$ Neden? Bunun başlıca nedeni eyleyen ve yapının birbirlerinden ayrılmaz olmasıdır. Bourdieu işte tam da bu nokta da habitus kavramını ortaya atıp yapıyla eyleyen arasında bir bağ kurup bu iki unsurun birbirlerini aynı anda karşılıklı olarak inşa ettiklerini (coconstitution) iddia edecektir. Bu durum da alan ve eyleyenler düzeyinde meydana gelen değişimleri daha iyi kavramamıza yardımcı olacaktır.

Bir sonraki aşama da ise, Bourdieu habitus kavramına tarihi boyutu (ya da geçmiş tecrübeleri) de eklemektedir. Böylece belirli bir geçmişten köklerini alıp eyleyenlerin şimdiki zamandaki eylemlerini etkileyen tarihsel unsurlar da analize dâhil edilmektedir. $\mathrm{Bu}$ düşünceyi Türk Dış Politikası'na uyarlarsak, Türk karar alıcıların SSCB'ye yönelik besledikleri "düşman" algilaması ve bunun neticesinde de başında bulundukları devlet-eyleyenin eylemlerini oluşturdukları sosyal bağlamı salt Soğuk Savaş dinamikleri veya realpolitik nedenlerle açıklamak yetersiz kalmaktadır. Türk karar alıcılar tercihlerini oluştururken realpolitik nedenlerin yanı sıra bu tercihleri tarihsel kökleri daha derinlerde bulunan ve Osmanlı İmparatorluğu ile Çarlık Rusya’sı arasında geçmişten günümüze meydana gelen çok sayıdaki savaşların mirasının da etkisinde kalarak oluşturmuşlardır. Dolayısıyla bu tarihsel miras, Türk karar alıcıların "jenerik bir Rus imajı” inşa etmesinde etkili bir parametre oluşturmaktadır. Bu nedenle de bu durum Soğuk Savaş dönemindeki Türk dış politikası incelenirken dikkate alınması gereken bir unsurdur. Tarihten gelen bu "Rus imajının" sadece karar alıcıların algılarını (ya da bilişsel dünyasını) biçimlendirmekle kalmayıp, halkın (plèbe) bilincine kadar da nüfûz ettiğini söylemek mümkün, zira bunun

71 Bourdieu, Esquisse d'une Théorie, s.262. 
yansımaları günlük hâlk dilinde de yaygın şekilde görülmektedir. ${ }^{72}$ Dolayısıyla alan ve habitus kavramlarının Uluslararası İlişkiler kuramlarına dâhil edilmesi Anna Leander'in de ifade ettiği gibi bu alandaki eyleyenlerin uygulamalarıyla söylemleri arasındaki ilişkiyi göstermek açısından yararlı olmakla beraber, aynı zamanda Uluslararası İlişkiler'deki ana akım kuramların düşünce kalıplarından çıkmamızı da sağlayıp eyleyenleri çevreleyen sosyal koşullara ve gerçekliklere eleştirel bir bakış açısıyla yaklaşmamızı sağlamaktadır. ${ }^{73} \mathrm{Bu}$ unsurların yanı sıra, alan ve habitus kavramaları ayrıca ana akım kuramların ssrarla vurgu yaptığı materyal unsurlardan bir nebze olsun sıyrılmamızı sağlayıp, uluslararası politikada eyleyenlerin uygulamalarını etkileyen düşünce, inanç ve ideoloji gibi materyal olmayan unsurları da dikkate almamızı sağlayarak kuram içindeki yapıyla eyleyen arasındaki dikotomik ilişkinin bir nebze olsun aşılmasına yardımcı olmaktadır. ${ }^{74} \mathrm{Bu}$ dikotomik uçurumun azaltılması eyleyenlerin materyal olmayan bu unsurlarının yapıyı ne şekilde etkilediğini ve tersine dönüşüm geçirip evrilen yapının da eyleyenlerin kimliklerini ve uygulamalarını ne ölçüde değişime zorladığını göstermek açısından oldukça faydalı görünmektedir.

Alan ve habitus kavramlarının Uluslararasi İlişkiler kuramlarına nihayet son katkısı da siyasi alanı herşeyden önce bir mücadele sahası olarak görüp, belirli bir alan içindeki söz konusu mücadeleleri sadece materyal unsurların ve kaynakların ele geçirilmesi "sava§̧1" olarak görmeyip, bunlara ayrıca eyleyenlerin eşit olmayan kapitaller (maddi ve maddi olmayan) vasıtasıyla birbirlerine karşı verdikleri simgesel mücadeleleri de (luttes symboliques) eklemesidir. Bourdieu'ye göre bir kuram eyleyenlerin birbirleriyle ilgili etkileşimlerini açıklama çabasına girdiğinde eyleyenlerin sosyal dünyayla ilgili betimlemelerini de açıklayıcı mekanizmalara dâhil etmelidir. Alan nosyonu tam da bu nokta da analize dâhil olup eyleyenlerin kendi sosyal dünya ile ilgili betimleme ve algılarını diğer eyleyenlere dayatmak için verdikleri mücadeleleri anlamaya dönük bir mekanizma olarak işlemektedir. ${ }^{75}$ Bourdieu'nün bu konuyla ilgili argümanlarını uluslararası ilişkilerdeki güncel siyasi sorunlarla ilişkilendirmek gerekirse akla ilk gelen Irak ve Afganistan örnekleridir. Hatırlanabileceği gibi Irak’a 2003 yılında koalisyon güçleri tarafından gerçekleştirilen askeri müdahaleden önce ABD'deki Bush ve İngiltere'deki Blair yönetimleri Saddam Hüseyin yönetiminin elinde kuşku götürmez şekilde kitle imha silahları bulunduğunu ve bunların kullanılması durumunda tüm Orta Doğu'nun istikrarsızlı̆̆a sürükleneceğini öne sürerek bu yönetimin gerek Birleşmis Milletler nezninde gerekse diğer uluslararası platformlarda devrilmesini meşru kılmaya yönelik söylem ve çabalar içerisinde bulunmuşlardır. Afganistan örneğinde ise Bush yönetimi'nin 11 Eylül 2001 y1lındaki ABD’ye gerçekleştirilen saldırıların ardından uluslararası sistemde Afganistan'a olası bir müdaheleyi

72 Örneğin Moskof kelimesinin karşılığı Türk Dil Kurumu'nun Büyük Türkçe Sözlüğünde "acımasız, zâlim” olarak tarif edilmektedir. Bu örneğe hâlk dilindeki "Moskof kızından kadın olmaz", "Moskof gâvuru" gibi diğer olumsuz metaforlarda eklenebilir.

73 Anna Leander, “Thinking Tools”, Audie Klotz ve Deepa Prakash (der.), Qualitative Methods in International Relations- A Pluralist Guide, New York, MacMillan, 2008, s.11-27.

74 Anna Leander, "Habitus and Field", 30 Kasım 2009, http:// openarchive.cbs.dk/bitstream/ handle/10398/7966/Habitus_and_Field_Working_Paper.pdf?sequence=1 (Erişim Tarihi 7 Ocak 2014).

75 Bourdieu, Propos sur le Champ Politique, s.61-91. 
meşru kılmak için hangi devlet-eyleyenin "iyi” ya da "dost" hangisinin "kötü" veya "haydut" kategorisinde bulunduğuna yönelik doğruları, yanlışları, iyileri ve kötüleri belirlemeye yönelik söylemleri bir gerçeklik gibi yansıtması akla gelmektedir. ${ }^{76}$ Görülebileceği gibi Bourdieu'nün yukarıdaki argümanları yönetici etlitlerin söylem ve algılarının devletlerin eylemlerini ne şekilde harekete geçirdiğini daha somut bir şekilde düşünmemizi sağlamak açısından oldukça faydalı görünmektedir.

Netice de Bourdieu'nün de ifade ettiği gibi habitus ile alan kavramları sosyal dünya ile eyleyeni bir araya getirebilmeyi sağlayıp, eyleyeni ve onu çevreleyen sosyal dünyayı eş zamanlı incelebilmemizi sağlamaktadır. ${ }^{77}$ Sonuç itibariyle alan ve babitus kavramlarının analizlere dâhil edilmesi yerel, ulusal ve uluslararası arena gibi çok seviyeli (échelles multiples) ve alanlarn (ekonomik, güvenlik, ekolojik vs.) birbiriyle mukayesesini mümkün kılacak incelemeleri, bunun yanı sıra, uluslararası ilişkiler literatürünü yazanları da yapı bozuma uğratıp, karşl1ıklı bir öznelliğin (intersubjectivité) bu alanda tesis edilmesini sağlamaktadır.

İllusio nosyonuna gelecek olursak, bu da eyleyenlerin maddi (ekonomik) kazançlarının yanı sıra bilişsel ve eylemlerini tetikleyen sembolik unsurların analizlerde hesaba katılmasını öngörmektedir. İllusio nosyonu ayrıca eyleyenlerin tümüyle oyunun dışında kalmadan belirli olgulara karşı bilinçli veya bilinçsiz bir şekilde ilgisiz kalabileceğini de hesaba katmaktadır. Oysa ana akım tâbir edilen kuramlar (özellikle Gerçekçi ve liberal), aktörlerin uluslararası sistem içindeki tehditlere ilgisiz kalamayacağını, kalması durumunda ise varoluşlarının tehtid altında olacağını varsaymaktadır. Bu açıdan illusio nosyonu uluslararası sistemde "boşluk" (vacuo) kabul etmeyen ve bu sistemdeki oyunu "bilardo topları" metaforu prizmasından değerlendirip eyleyenlerin mutlak surette etkileşim halinde bulunacağını varsayan ana akım kuramların analizlerinden belirli farklılıklar göstermektedir. Bilindiği gibi uluslararası siyasette eyleyenlerin bazen bazı olgulara kar§̧1 "sessiz" kalması dâhi aslında bu olguları dolaylı olarak tanıma/kabul etme anlamına gelmektedir. Diğer bir deyişle fiziki eylemsizlik veya diplomatik sessizlik diplomatik bir tutumun olmadığı anlamına gelmemektedir. Bu "eylemsizliğin eylem hali" (la position sans l'interaction) ana akım kuramların gözden kaçırdığ 1 bir noktadır. Ana akım kuramlar ayrıca çıkar kavramını verili bir olgu gibi kabul ettiğinden bunun oluşturulma sürecini de gözden kaçırıp netice de çıkar kavramının inşa edildiği belirli bir alanda hangi eyleyenlerin oyuna dâhil olduğunu hangi eyleyenin ne tür bir kapitalle (maddi, sembolik, normatif gibi) bu oyuna giriştiğini açıklamak da yetersiz kalmaktadırlar. Dolayısıyla Mérand ve Pouliot'nun da ifade ettiği gibi, illusio nosyonu çıkar kavramının oluşturulma sürecinde ortaya çıkan mücadeleleri ve bu alanda kaynakların dağıtımının ne şekilde gerçekleştiğini de göstermek açısından faydalıdır. ${ }^{78}$

76 Bush yönetiminin Irak ve Afganistan konusundaki söylemlerinin Uluslararası İlişkiler kuramları perspektifinden ayrıntılı analizi için bkz. Richard Devetak, "The Gothic Scene of International Relations: Ghosts, Monsters, Terror and the Sublime After September 11", Review of International Studies, Cilt 31, No.4, 2005, s.621-643.

77 Pierre Bourdieu ve Loic J.D. Wacquant, Réponses pour une Anthropologie Réflexive, Paris, Éditions du Seuil, 1992, s.102-104.

78 Mérand ve Pouliot, "Le Monde de Pierre Bourdieu”, s.614. 
Bourdieu ayrıca rasyonalist paradigmanın geleneksel hatasının belirli bir sosyal alandaki oyunun oynanma kurallarını diğer alanlarda da verili gibi kabul etmesinde yattığını, bu durumun da iktisadi (maliyet, kazanç ve hesap kurgusunda olduğu gibi) oyun kurallarının diğer alanlarda da benzer bir şekilde işlediğini iddia etmek anlamına geldiğini savunacaktır. Oysa ona göre ekonomik alanda eyleyenleri mücadeleye sürükleyen temel dürtüler örneğin bilimsel alanda eyleyenleri karşı karşıya getiren motivasyonlarla aynı değildir. ${ }^{79}$ Bundan dolayı Bourdieu dürtülerin ve sembolik unsurların da eyleyenlerin eylemlerini harekete geçiren unsurlar olarak analize dâhil edilmesini teklif edecektir. Bu durumda rasyonalist paradigmanın prizmasından İran veya Kuzey Kore gibi devletlerin son zamanlardaki diplomatik "hırçkınlıklarını" değerlendirmek gerektiğinde, bunları salt kendilerine karşı uygulanan ekonomik ambargolara karşı geliştirdikleri bir davranış biçimi veya uluslararası sistemde "maddi" çıkar arayışları olarak değerlendirmekle yetinmek zorunda kalırız. Oysa bu "hırçkınlıklar" aynı zamanda uluslararası ilişkiler alanında sembolik veya kimliksel hedefleri elde etmek için geliştirilen diplomatik pratikler olarak da karşımıza çıkmaktadır. Örneğin İran'ın 2003 ila 2005 yılları arasında nükleer meselelerdeki müzakerelerini yürütmekle sorumlu üst düzey bir yetkili son zamanlarda yaptığı bir açıklamada artık nükleer sorunun İran'ın ulusal bir kimlik meselesi haline dönüştüğünü ve bu alandaki yapılan çalışmaların mîlli kıvanç kaynağı oluşturduğunu açıklamıştır. ${ }^{80}$ Netice de silahlı veya diplomatik yollardan İran'n bu haktan mahrum edilmesi, ulusal kimliğine karşı yöneltilen bir saldırı olarak algılanacaktır. Oysa İran örneğinde de görüleceği gibi nükleer sorun artık salt teknolojik veya askeri bir nitelik taşımamaktadır, bu ülkenin elitleri tarafından bir hâk davası veya mîlli övünç kaynağı olarak algılanmakta, bunu muhâfaza etmek için bu ülkenin elitleri silahlı çatışmayı dâhi göze almaktadırlar. Dolayısıyla uluslararası siyasette eyleyenler her zaman salt maddi anlamda maksimum kazanç elde etmek için değil, bazen doğru olduklarına inandıkları değerler, kimlikleri, onurları veya bir haksızlığa karşı koymak ve verdikleri bu tür mücadelenin diğer eyleyenler tarafindan tanınması için de diplomatik çaba veya silahlı çatı̧̧mayı göze alabilirler.

İllusio ile diğer bir unsur da, ana akım kuramların çıkar kavramı kapsamında devlet-eyleyenlerin eylemlerini ancak "stratejik niyetler" çerçevesinde gerçekleştirdiğiyle ilgilidir. Bourdieu bunun sosyal dünya da çok nadiren görülebileceğini ifade etmektedir. ${ }^{81}$ İllusio kavramı bu aşama da eyleyenlerin "rutin eylemlerini" kriz yönetimi altındaki "stratejik eylemlerinden" ayırmaktadır. Diğer bir deyişle, illusio eyleyenlerin tüm eylemlerini top yekûn "stratejik" bir refleksle gerçekleştirmeyeceklerini de dikkate almaktadır. Eyleme yönelik bu farklılığın dikkate alınması dış politika alanında eyleyenlerin eylemlerini daha farklı bir perspektifden okumamızı sağlamaktadır, zira uluslararası ilişkiler de her olgunun (ideolojik, tarihi, ekonomik vs.) kendine has özellikleri olduğunundan eyleyenler eylemlerini bu özellikler doğrultusunda geliştireceklerdir. Dolayısıyla illusio eyleyenlerin eylemlerini uluslararası arenada genelleştirmekten kaçınmamızı da sağlamaktadır.

79 Bourdieu, Raisons Pratiques, s.158. Ayrıca eyleyenlerin kimliklerinin, itibârlarının, statülerinin ve belirli bir alandaki rollerinin tanınmasına ilişkin Bourdieu'nün ayrıntılı görüşleri için bkz. Pierre Bourdieu, Méditations Pascaliennes, s.239-242.

80 Seyyed Hossein Moussavian ile yapılan röportaj, "Le Nucléaire Est Devenu La Clé De Voûte Du Nation İranien”, Le Monde, 4 Şubat 2012, s.4.

81 Bourdieu, Raisons Pratiques, s.156. 
Rasyonalist paradigmalar belirli bir saha içinde "jenerik" olarak oluşturulan rasyonel aktörlerin "hamle ve karşı hamle" doğrultusunda diplomatik hareketlerini geliştirdiklerini varsaymaktadırlar. Oysa Bourdieu eyleyenin belirli bir sosyal doku içerisinde oluşturulan kural ve normlar doğrultusunda hareket ettiğini savunmaktadır. Bu durum hem eyleyenlerin eylemlerini salt "mekanik" etkileşimler olarak görmememiz gerektiğini, hem de iktisatçıların jenerik, tarihten arındırılmış (a-historic), verili ve doğal olarak sunduğu çıkar kavramının tersine söz konusu olgunun herşeyden önce habitus'ün düzenlemeleri tarafindan belirlendiği anlamına gelmektedir. Bu nedenle Bourdieu her ampirik örnek olayda söz konusu "çıkarların" ve bunların "içeriklerinin" üretildiği sosyal koşulların ortaya çıkarılmasında ısrar etmektedir. ${ }^{82} \mathrm{Bu}$ açıdan da Bourdieu'cü analizin dış politika analizi (Foreign Policy Analysis) ve inşacı (constructiviste) akımlarla ortak noktaları bulunduğunu görmek mümkün, zira bu akımların savunucuları gibi o da "çıkar" diye tabir edilen olgunun oluşturulma sürecini ve bu süreçte eyleyenler arasında cereyan eden mücadelelerin ortaya çıkarılması gerektiğine inanmaktadır. Dolayısıyla ona göre belirli bir alanda verili "bir" değil, inşa edilmiş "bir dizi” çıkar şekilleri bulunmaktadır.

\section{Sonuç}

Bourdieu'cü okuma öncelikle Uluslararası İlişkiler disiplininin asli unsuru olan ve Gerçekçi paradigmanın 1srarla üzerinde durduğu devlet-eyleyenlerin sosyolojik bir perspektiften incelenmesini mümkün kılarak, diyakronik bir yaklaşımla, onların tarihsel evriminin günlük rutin aktivitelerini nasıl etkilediğini ortaya çıkarabilmektedir. Bourdieu'cü analizle ayrıca alan kavramı prizmasından gerek uluslararası sistem gerekse ulusal ve yerel ölçekli eyleyenler arasındaki etkileşimler dikkate alınarak hangi ölçekte ne tür eyleyenlerin "oyuna" dâhil olduğu hangilerinin dışlandığı gösterilebilmektedir. Böylece eyleyenler arasındaki sosyalizasyon süreçlerinin nasıl işlediği ve bu süreçler de eyleyenler arasındaki baskın/ edilgen ilişkiler yumağı daha açık bir şekilde ortaya konulabilmektedir. Bourdieu'nün diğer bir katkısı da "güç" nosyonu konusundadır. Gücün farklı şekil ve uygulamalar da görülebileceğinin altını çizen Bourdieu, bu yolla disiplin içerisinde genelde salt askeri bir unsur olarak değerlendirilen güç nosyonunun daha geniş bir yelpazeden ele alınmasını sağlamaktadır. Böylece gücün neyi tetiklediğini (savaş, çatışma gibi) anlamaktansa, onun hem maddi hem de maddi olmayan unsurlardan oluştuğu dikkate alınarak, nasıl ve hangi unsurlar üzerine kurulu olduğu ortaya çıkarılabilmektedir. Diğer önemli bir katkı da "değişimlerle" ilgilidir. Bu noktada Bourdieu habitus kavramını devreye sokarak gerek sosyal dokunun gerekse bu doku içerisinde bulunan eyleyenlerin birbirleriyle yinelemeli (itérative) etkileşimleri sonucunda nasıl dönüştüğüne 1ş1k tutabilmektedir. Nihayet son katkısı da epistemoloji alanındadır. Bilimsel üretim mekanizmalarında öznelliğe vurgu yapan Bourdieu bilimselliğin de öznel bir kurgudan ibaret olduğunu ve üretilen bilginin nötr olmadığını, ayrıca epistemolojik kutuplaşmaların mutedil epistemolojik bir "orta yolla" aşılabileceğini göstererek sosyal bilimlere bu alanda da katkı sağlamaktadır.

82 Bourdieu, Les Choses Dites, s.62-63. 


\section{Kaynakça}

Accardo, Alain, Introduction à une Sociologie Critique- Lire Bourdieu, Bordeaux, Éditions le Mascaret, 1997.

Accardo, Alain ve Corcuff, Philippe, La Sociologie de Bourdieu- Textes Choisis et Commentés, Bordeaux, Éditions Le Mascaret, 1986.

Addi, Lahouari, «Violence Symbolique et Statut du Politique chez Pierre Bourdieu », Revue Française de Science Politique, No 6, 2001, s. 949-963.

Adler, Emanuel ve Pouliot, Vincent, International Practices, New York, Cambridge University Press, 2011.

Adler-Nissen, Rebecca (der.), Bourdieu in International Relations- Retbinking Key Concepts in $I R$, New York, Routledge, 2013.

Adler-Nissen, Rebecca, "Bourdieu and International Relations Theory ", Rebecca, AdlerNissen (der.), Bourdieu in International Relations-Retbinking Key Concepts in IR, New York, Routledge, 2013, s.1-23.

Adler-Nissen, Rebecca, "The State's Symbolic Power and Transnational Fields », Rebecca, Adler-Nissen (der.), Bourdieu in International Relations- Rethinking Key Concepts in IR, New York, Routledge, 2013, s.179-192.

Adler-Nissen, Rebecca, «Inter and Transnational Field(s) of Power- On A Field Trip With Bourdieu », International Political Sociology, Cilt 5, No 3, 2011, s.327-345.

Ashley, Richard, "The Poverty of Neorealism ", International Organization, Cilt 38, No 2, 1984, s. 225-286.

Badie, Bertrand ve Birnbaum, Pierre, Sociologie de l'État, Paris, Grasset, 1979.

Bartelson, Jens, The Critique of The State, New York, Cambridge University Press, 2003.

Bartelson, Jens, A Genealogy of Sovereignty, New York, Cambridge University Press, 1995.

Bigo, Didier, «Pierre Bourdieu and International Relations: Power of Practices, Practices of Power », International Political Sociology, Cilt 5, No 3, 2011, s. 225-258.

Bigo, Didier ve Tsoukala, Anastassia (der.), Terror, Insecurity and Liberty-Illiberal Practices of Liberal Regimes After 9/11, New York, 2008.

Bigo, Didier, «L'Europe de la Sécurité Intérieure- Penser Autrement la Sécurité ", AnneMarie le Gloannec (der.), Entre Union et Nations, Paris, Presses de Sciences Po., 1998, s.55-90.

Bigo, Didier, Polices en Réseaux : l'Expérience Européenne, Paris, Presses de Sciences Po., 1996.

Bourdieu, Pierre, Sur l'État-Cours au Collège de France 1989-1992, Paris, Raisons d'Agir/Seuil, 2012.

Bourdieu, Pierre, Méditations Pascaliennes, Paris, Éditions du Seuil, 2003.

Bourdieu, Pierre, Questions de Sociologie, Paris, Éditions de Minuit, 2002.

Bourdieu, Pierre, Contre-feux 2, Paris, Raisons d'Agir, 2001.

Bourdieu, Pierre, Langage et Pouvoir Symbolique, Paris, Éditions du Seuil, 2001.

Bourdieu, Pierre, Science de la Science et Réflexivité, Paris, Éditions raison d'Agir, 2001.

Bourdieu, Pierre, Esquisse d'une Théorie de la Pratique- Précédé de Trois Études d'Ethnologie Kabyle, Paris, Éditions du Seuil, 2000. [İlk baskısı 1972 yılında Droz yayınevinden piyasaya çıkmışır]. 
Bourdieu, Pierre, Propos sur le Champ Politique-avec une introduction de Philippe Fritsch, Lyon, Presses Universitaires de Lyon, 2000.

Bourdieu, Pierre, Contre-feux 1. Propos pour Servir à la Résistance contre l'Invasion Néo-libérale, Paris, Liber/Raisons d'Agir, 1998.

Bourdieu, Pierre, Raisons pratiques. Sur la Théorie de l'Action, Paris, Éditions du Seuil, 1994.

Bourdieu, Pierre, "Rethinking the State: Genesis and Structure of Bureaucratic Field ", Sociological Theory, Cilt 12, No 1, 1994, s. 1-18.

Bourdieu, Pierre ve Wacquant, Loic J.D., Réponses pour une Anthropologie Réflexive, Paris, Éditions du Seuil, 1992.

Bourdieu, Pierre, Choses Dites, Paris, Éditions Minuit, 1987.

Bourdieu, Pierre et al., Le Métier de Sociologue, Paris, Éditions Minuit, 4’ncü baskı, 1983.

Bourdieu, Pierre, Le Sens Pratique, Paris, Éditions Minuit, 1980.

Bourdieu, Pierre, « Les Modes de Domination », Actes de la Recherche en Sciences Sociales, Cilt 2, No 2/3, 1976, s. 122-132.

Bourdieu, Pierre ve Passeron, Jean-Claude, La Reproduction. Éléments pour une Théorie du Système d'Enseignement, Paris, Minuit, 1970.

Brubaker, Roger, « Rethinking Classical Theory: The Sociological Vision of Pierre Bourdieu », Theory and Society, Cilt 14, 1985, s. 745-775.

Champagne, Patrick ve Christin, Olivier, Pierre Bourdieu- une initiation, Lyon, Presses Universitaires de Lyon, 2012.

Cox, Robert W., « Social Forces, States and World Order : Beyond International Relations Theory ", Robert O. Keohane (der.), Neorealism and its Critics, New York, Columbia University Press, 1986, s. 204-254.

Devetak, Richard, «The Gothic Scene of International Relations: Ghosts, Monsters, Terror and the Sublime After September 11 ", Review of International Studies, Cilt 31, No 4, 2005, s. 621-643.

Eagleton-Pierce, Matthew, « Examining the Case for Reflexivity in International Relations: Insights from Bourdieu ", Journal of Critical Globalization Studies, No 1, 2009, s. 111-123.

Elias, Norbert, La Dynamique de l'Occident, Paris, Pocket collection Agora, 1990.

Forget, Amélie ve Rayroux, Antoine, «Introduction: la Sécurité Européenne et le Tournant Pratique des Relations Internationales ", Études internationales, Cilt 43, No 4, 2012, s. 501-519.

Garcia, Francisco Vazquez, « La Tension Infinie entre l'Histoire et la Raison: Foucault et Bourdieu », Revue internationale de philosophie, No ${ }^{\circ} 220$, 2002, s. 343-365.

Guzzini, Stefano, «A Reconstruction of Constructivism in International Relations ", European Journal of International Relations, Cilt 6, No 2, 2000, s. 147-182.

Hibou, Béatrice (der.), La Privatisation des États, Paris, Karthala, 1999.

Jackson, Robert H., Quasi-States : Sovereignty, International Relations and the Third World, Cambridge, Cambridge University Press, 1996.

Jourdain, Anne ve Naulin, Sidonie (der.), La Théorie de Pierre Bourdieu et Ses Usages Sociologiques, Paris, Armand Colin, 2011. 
Kauppi, Niilo, "Boudieu's Political Sociology and the Politics of European Integration ", Theory and Society, Cilt 32, No 5/6, 2003, s. 775-789.

Lane, Jeremy F., Bourdieu's Politics- Problems and Possibilities, New York, Routledge, 2008.

Lapid, Yosef, «The Third Debate: On the Prospects of International Theory in a Post-Positivist Era », International Studies Quarterly, Cilt 33, No 3, 1989, s. 235-254.

Larkins, Jeremy, From Hierarchy to Anarchy-Territory and Politics Before Westphalia, New York, Palgrave Macmillan, 2010.

Leander, Anna, « The Promises, Problems, and Potentials of a Bourdieu-Inspired Staging of International Relations ", International Political Sociology, Cilt 5, No 3, 2011, s. 294-313.

Leander, Anna, « Habitus and Field », 30 Kasım 2009, http://openarchive.cbs.dk/bitstream/ handle/10398/7966/Habitus_and_Field_Working_Paper.pdf?sequence=1 (Erişim tarihi 7 Ocak 2014).

Leander, Anna, « Securing Sovereignty by Governing Security Markets », Rebecca AdlerNissen ve Thomas Gammeltoft-Hansen (der.), Sovereignty Games - Instrumentalizing State Sovereignty in Europe and Beyond, New York, Palgrave Macmillan, 2008, s.151170.

Leander, Anna, «Thinking Tools », Audie Klotz ve Deepa Prakash (der.), Qualitative Methods in International Relations-A Pluralist Guide, New York, MacMillan, 2008, s. 11-27.

Leander, Anna, «The Power to Construct International Security: On the Signifiance of Private Military Companies ", Millenium Journal of International Studies, Cilt 33, No 3, 2005, s. 803-826.

McSweeney, Bill, Seurity, Identity and Interest-A Sociology of International Relations, Cambridge, Cambridge University Press, 1999.

Mérand, Frédéric ve Pouliot, Vincent, « Le Monde de Pierre Bourdieu: Éléments pour une Théorie Sociale des Relations internationales ", Canadian Journal of Political Science, Cilt 41, No 3, 2008, s. 603-625.

Oren, Ido, « Political Science As History: A Reflexive Approach », Dvora Yanow ve Peregrine Schwartz-Shea (der.), Interpretation and Method-Empirical Research Method and The Interpretive Turn, New York, M.E Sharpe, 2006, s.215-227.

Rotberg, Robert I. (der.), When State Fail: Causes and Consequences, New Jersey, Princeton University Press, 2004.

Swartz, David L. ve Zolberg, Vera L. (der.), After Bourdieu-Influence, Critique, Elaboration, Dordrecht, Kluwer Academic Publishers, 2004.

Thévenot, Laurent, "Pragmatic Regimes Governing The Engagement With the World », Theodore R. Schatzki et al., The Practice Turn in Contemporary Theory, New York, Routledge, 2001, s.64-82.

Weber, Max, Économie et Société, birinci ve ikinci ciltler, Paris, Plon, 1971.

Williams, Michael C., Culture and Security : Symbolic Power and the Politics of International Security, Londra, Routledge, 2007.

Wight, Colin, Agents, Structures and International Relations- Politics as Ontology, New York, Cambridge University Press, 2006.

Wolfers, Arnold, Discorde and Collaboration: Essay on International Politics, Baltimore, The John Hopkins Press, 1962. 


\section{Summary}

Within different theories of International Relations (IR), analyzes studying the contribution of Pierre Bourdieu to the discipline are still very limited. This observation is the opening of this article that focuses on the main ideas of Pierre Bourdieu to highlight these possible contributions to theories of IR.

In a first time, and considering the meta-theoretical rupture that exists on epistemological issues in theories of IR between positivist and post-positivist approaches, the article discusses the positions of Bourdieu's sociology about this epistemological bias. Based on the observation that the existing dichotomous conflicts between thesis two approaches in the social sciences are only artificial polarization, and therefore they are a sterile debate because one side opposes an approach that focuses on the interactions of agents to understand the structure and the other side an approach that emphasizes the characteristics of the structure to apprehend the interactions of agents, the article shows in which way, faced to this polarization, the sociology of Bourdieu opens "a middle course", offering a reflexive epistemology.

Also emphasizing that the issues related to the acquisition of knowledge and learning should particularly not be limited within the rigid framework of philosophy, since they may be the products of a habitus, the article shows as for Bourdieu sociology it is essential to (re)consider the production of such knowledge and skills that are often considered as "prior learning". The reflexive epistemology of Bourdieu therefore insists that knowledge and skills are only a construction, arose of a process and in this context it recommends to (re)question them by proposing an objectification of objectivity.

In the theories of IR, this situation returns to reject the positivist models on which current mainstream theories are based. In other words, it is necessary to (re)questioning several concepts that are considered "re-aquired" within the discipline such as State, sovereignty, anarchy, etc...

In a second step, the article argues that the contribution of Bourdieu's approach is not limited just to the elements it offers in epistemological terms, but it contributes significantly on the ontological level. Therefore, the article reveals that Bourdieu's approach strives on the one hand to exceed subjectivism which tends to conclude that the structure is shaped by the actions of players and on the other hand a positivism "reificator" which tends to propose in an abstract way the agents. And relying selectively on certain concepts developed by Pierre Bourdieu as agent, habitus, field and illusio, the paper demonstrates that this approach strives to create a dialogical relationship between "the reality of the model" and "the model of reality" to overcome these ontological discords by relying on a "relational ontology". Finally to turn this "relational ontology" of Bourdieu into the concrete, this article details in a analytical way these concepts and it strives to adapt to the theories of IR by illustrating in a practical way the possible applications.

On the ontological level, the article concludes that Bourdieu's relational ontology can develop in detail a sociological profile of political units that populate the international arena, and in this way it contributes to "sociologize" entities (such as for example States) that are offered in a "generic" and "homogeneous" way by the dominant paradigms of the- 
ories of IR. It also shows that the relational ontology allows to dissect the different shapes and applications of the concept of power, and taking in some way away with the notion of power designed primarily as a military/material aspect by mainstream paradigms, Bourdieu's approach suggests a broader range of the concept of power in international relations.

Finally, adapting the concept of field in the theories of IR, the article also explains that this concept can provide a better understanding of the various interactions that are taking place between the different agents at different scales (local, national, international) and that in that way it may help to dissect the action itself. Thus, the analysis grid based on the concept of field is used to clarify the socialization process between agents and in this way to identify the complex relationships that exist between dominant and dominated agents in a particular area. 